\title{
Impact of Afternoon Thunderstorms on the Land-Sea Breeze in the Taipei Basin during Summer: An Experiment*
}

\author{
TSING-CHANG CHEN \\ Department of Geological and Atmospheric Sciences, Iowa State University, Ames, Iowa \\ MING-CHENG YEN \\ Department of Atmospheric Sciences, National Central University, Chung-Li, Taiwan \\ JENQ-DAR TSAY \\ Department of Geological and Atmospheric Sciences, Iowa State University, Ames, Iowa \\ CHI-CHANG LiaO \\ Department of Environmental Information and Engineering, Chung-Cheng Institute of Technology, National \\ Defense University, Taoyuan, Taiwan \\ EUGENE S. TAKLE \\ Department of Geological and Atmospheric Sciences, and Department of Agronomy, Iowa State University, Ames, Iowa
}

(Manuscript received 11 March 2013, in final form 10 February 2014)

\begin{abstract}
Environmental conditions for the roughly three million people living in the Taipei basin of Taiwan are greatly affected by the land-sea breeze and afternoon thunderstorm activities. A new perspective on the landsea breeze life cycle and how it is affected by afternoon thunderstorm activity in the Taipei basin during the dry season is provided. During the summer monsoon break-revival phase, about $75 \%$ of rainfall in the Taipei basin is produced by afternoon thunderstorms triggered by sea-breeze interactions with the mountains to the south of this basin. Because the basic characteristics of the land-sea breeze and the changes it undergoes through the influence of afternoon thunderstorms have not been comprehensively analyzed/documented, a mini-field experiment was conducted during the summers of 2004 and 2005 to explore these aspects of the land-sea breeze in this basin. Thunderstorm rainfall is found to change not only the basin's land-sea-breeze life cycle, but also its ventilation mechanism. On the nonthunderstorm day, the sea breeze supplies the opensea fresh air for about $8 \mathrm{~h}$ during the daytime, but the land breeze persists on the thunderstorm day from afternoon to the next morning, acting to sweep polluted urban air out of the basin.
\end{abstract}

\section{Introduction}

The air quality, municipal water supply, and air and land traffic hazards for three million people in the Taipei

\footnotetext{
* Supplemental information related to this paper is available at the Journals Online website: http://dx.doi.org/10.1175/JAMC-D-13-098.s1.

Corresponding author address: Tsing-Chang (Mike) Chen, Atmospheric Science Program, Dept. of Geological and Atmospheric Sciences, 3010 Agronomy Hall, Iowa State University, Ames, IA 50011. E-mail: tmchen@iastate.edu
}

basin of Taiwan during the summer season are strongly influenced by thunderstorms and their unique interaction with the land-sea-breeze circulation. Formed by the intersection of the Tanshui and Keelung River valleys, the Taipei basin is located in northern Taiwan, surrounded by mountains in three directions (north, southwest, and southeast), and is connected to the open sea through these two river valleys. The East Asian summer monsoon season is a dry season in northern Taiwan but is the maximum rainfall season in the Taipei basin (Chen et al. 2007, hereinafter C7). Exploring the cause of the interdecadal increase of summer rainfall in this basin produced by 
afternoon thunderstorms over the period 1961-2000, C7 found this increasing rainfall trend coincides with thunderstorm occurrence frequency. In C7, the afternoon thunderstorm occurrence is attributed to the interaction of the sea breeze with the urban heat island in the central Taipei District and mountains south of the Taipei basin. In view of this thunderstorm occurrence mechanism, basic issues are the underlying characteristics and life cycle of the land-sea breeze in this basin and the possible impact of thunderstorms on the land-sea-breeze circulation and the basin environment. To our knowledge, these issues have not been well investigated.

The development of the land-sea breeze is attributed to the land-sea thermal contrast (e.g., Simpson 1994). Because the soil's heat capacity is lower than that of the air, the thermal contrast between mountains and air masses aloft over the plain can affect the onset of land and sea breezes in response to sunrise and sunset. The surface cooling and downdraft of air masses by thunderstorm rainfall can facilitate the land-sea-breeze transition. A survey of some 30 previous studies of land-sea breezes and their impacts by afternoon thunderstorms provides some context for understanding the life cycle of land-sea breezes in the Taipei basin affected by three different constraints: 1) the case without any notable mountain near the sea coast (no-mountain case), 2) the case that is close to significant mountains (mountain case), and 3) the case that investigates the impact of afternoon thunderstorms (thunderstorm case). The onset times of land and sea breezes (LBs and SBs, respectively), as well as thunderstorm rainfall, are depicted in Fig. 1. Salient features of this figure are highlighted as follows.

1) These studies were conducted for the land-sea breezes in the subtropics and midlatitudes: sunrise occurs at about 0530 LST on average. The onset time of the sea breeze after sunrise is about $4+\mathrm{h}$ after sunrise for no-mountain cases, $3+\mathrm{h}$ for mountain cases, and $3.5 \mathrm{~h}$ for thunderstorm cases. These SB onset timings have the following implications:

- The mountain warming by the shortwave radiative heating moves the SB onset time earlier.

- The environment that is favorable for afternoon thunderstorm occurrence, presumably moister, facilitates the earlier SB onset.

2) Sunset is at $\sim 1900$ LST on average. The LB onset (SB cessation) time after sunset is $\sim 3.5 \mathrm{~h}$ for no-mountain cases, $\sim 0 \mathrm{~h}$ for mountain cases, and $\sim 3 \mathrm{~h}$ before sunset for thunderstorm (TS) cases. The synchronous occurrence of sunset and the LB onset implies the longwave radiative cooling is a decisive factor in LB trigger.

3) The life cycle of no-mountain SB (LB) is $\sim 12.5 \mathrm{~h}(11.5 \mathrm{~h})$, that for mountain $\mathrm{SB}$ (LB) is $\sim 10.5+\mathrm{h}(13.5+\mathrm{h})$, and that for TS SB (LB) is $\sim 6.5 \mathrm{~h}(17.5 \mathrm{~h})$.

This survey reveals how the life cycles of land-sea breezes can be affected by three factors: mountains, afternoon thunderstorms, and the large-scale environment. The Taipei basin is located within a special geographic/ orographic structure embedded in the East Asian summer monsoon. The basic environment in the Taipei basin should be affected by the three factors through sea-breeze interactions with the urban heat island and orography. Despite the observational mesonetwork formed from the facilities of different agencies within this basin, no systematic study has been conducted. To examine the effect of the three factors identified by Fig. 1 on the land-sea breeze circulation and the basin environment, a mini-field experiment (the Taipei Basin Experiment: TBEX) was performed over two summers (2004 and 2005) by enhancing the preexisting surface observational network and upper-air measurements with radiosonde, radar, and spaceborne observations. The improvements to the existing network enable us to obtain better observations of the submesoscale weather phenomena, so that the structure and temporal variation of the land-sea breeze in the Taipei basin, and the impact of afternoon thunderstorms on this basin land-sea breeze and the basin environment, can be more accurately depicted and understood.

Some details of TBEX, the necessary data, and the classification of the weather conditions/systems related to the land-sea breezes with and without afternoon thunderstorms are described in section 2. A benchmark diurnal variation of the basin environment established by the alternation of land and sea breezes within the Taipei basin without the afternoon thunderstorm activity is presented in section 3 . The necessary environmental conditions required for the development of afternoon thunderstorms is explored by contrasting a thunderstorm case presented in section 4 against the benchmark no-thunderstorm case shown in section 3. Because the major summer rainfall in the Taipei basin is produced by numerous thunderstorms, an effort is made in section 5, through simple statistical analyses, to confirm that the necessary conditions identified in section 4 are common to all identified thunderstorm cases. A summary of our major findings and some potential expansion of the present study for future research are presented in section 6.

\section{Network of observations and identification of thunderstorms}

\section{a. TBEX network of observations}

The potential impact of afternoon thunderstorms on the environment of the Taipei basin was inferred by C7. 


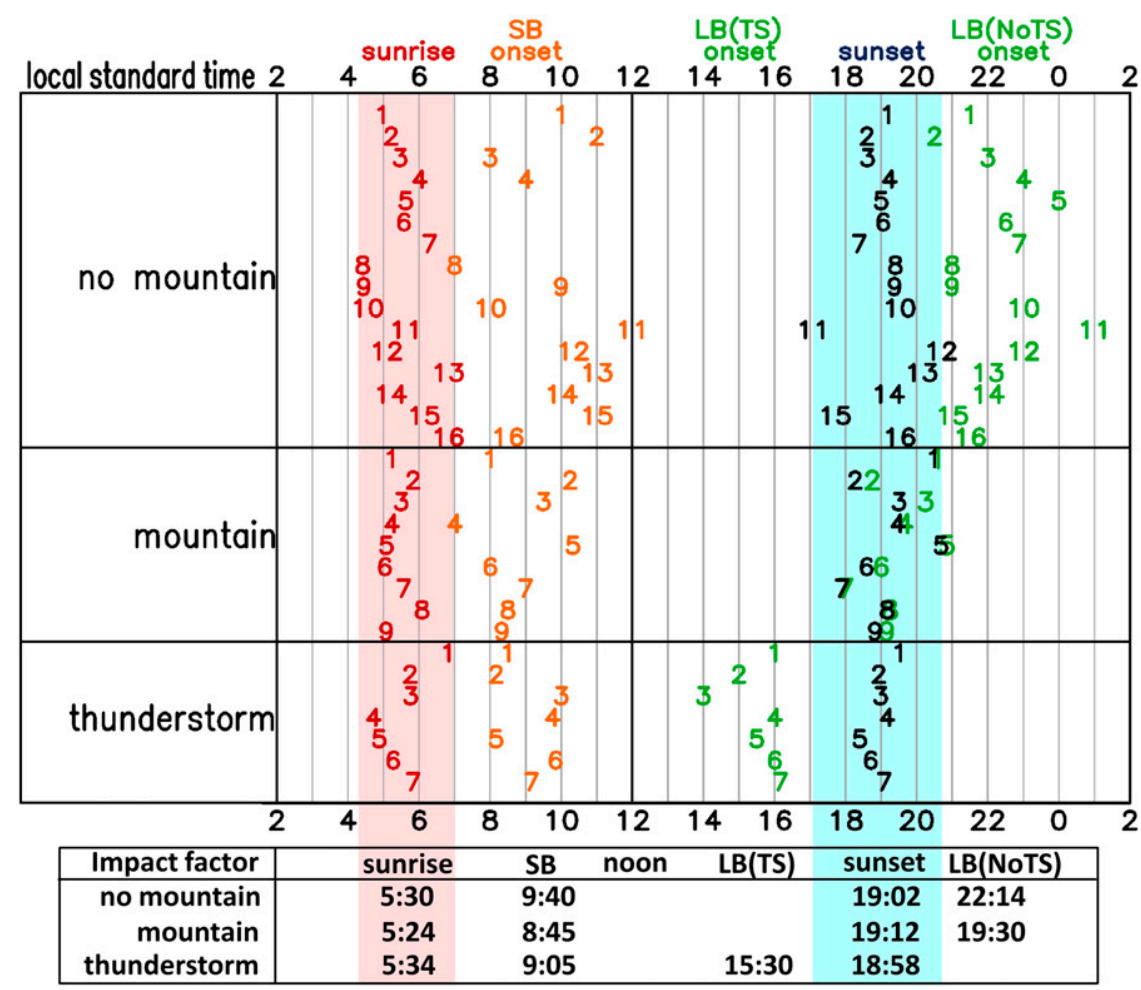

FIG. 1. A survey of the land-sea-breeze life cycle and how it is affected by no mountains near the shore, mountains close to the shore, and afternoon thunderstorms, taken from 32 previous studies during the past 50 years. The numbers shown in the three groups are studies listed at the end of this figure caption. Timing of sunrise, SB onset, LB onset followed by afternoon thunderstorms [LB(TS)], sunset, and LB onset without thunderstorms [LB(noTS)] are marked with study numbers. The averaged timings of the events listed near the top of the figure are tabulated at the bottom of the figure. References represented by numbers are classified into three groups: no mountain-1) Mizuma (1995), 2) Hill et al. (2010), 3) Meyer (1971), 4) Zhong and Takle (1992), 5-7) Case et al. (2005), 8) Fisher (1960), 9) Clappier et al. (2000), 10) Miao et al. (2003), 11) Eager et al. (2008), 12) Bastin and Drobinski (2006), 13) Simpson (1994), 14) Mastrantonio et al. (2008), 15) Panchal (1993), and 16) Oliphant et al. (2001); mountain-1) Hawkins (1977), 2) Banta (1995), 3) Furberg et al. (2002), 4) Park et al. (2012), 5) Bastin and Drobinski (2006), 6) Simpson (1994), 7) Sakurai et al. (2011), 8) Carbone et al. (1995), and 9) Prtenjak and Grisogono (2007); and thunderstorm-1) Oliphant et al. (2001), 2 and 3) Jury and Chiao (2013), 4) Sano and Tsuboki (2006), 5) Wilson et al. (2004), 6) Morales Rodriguez et al. (2010), and 7) Atkin and Wakimoto (1997).

This inference was primarily based on the analysis using surface observations made by a mesonet of preexisting surface stations (Fig. 2a).

To portray the details of the land-sea-breeze life cycle along the two river valleys and the submesoscale weather system associated with the development of afternoon thunderstorms within the Taipei basin, various extra stations were added to enhance the existing mesonet and to conduct more uniform and detailed measurements:

1) Surface stations-Conventional surface stations include 25 stations from the Central Weather Bureau
(CWB) of Taiwan, 73 stations from the Environmental Protection Administration (EPA), 6 stations from the Civil Aviation Administration (CAA), and several from Military Weather Forecast Centers. Seven mobile automatic weather observation stations (AWOSs) were installed primarily along the two river valleys, while 58 school-net stations were added over the western part of the Taipei basin. The landsea-breeze life cycle is depicted well by AWOS measurements along the river valleys. The school-net measurements enabled us to obtain a more detailed picture of the structure of the weather development inside the basin. 
(a) Network of observations

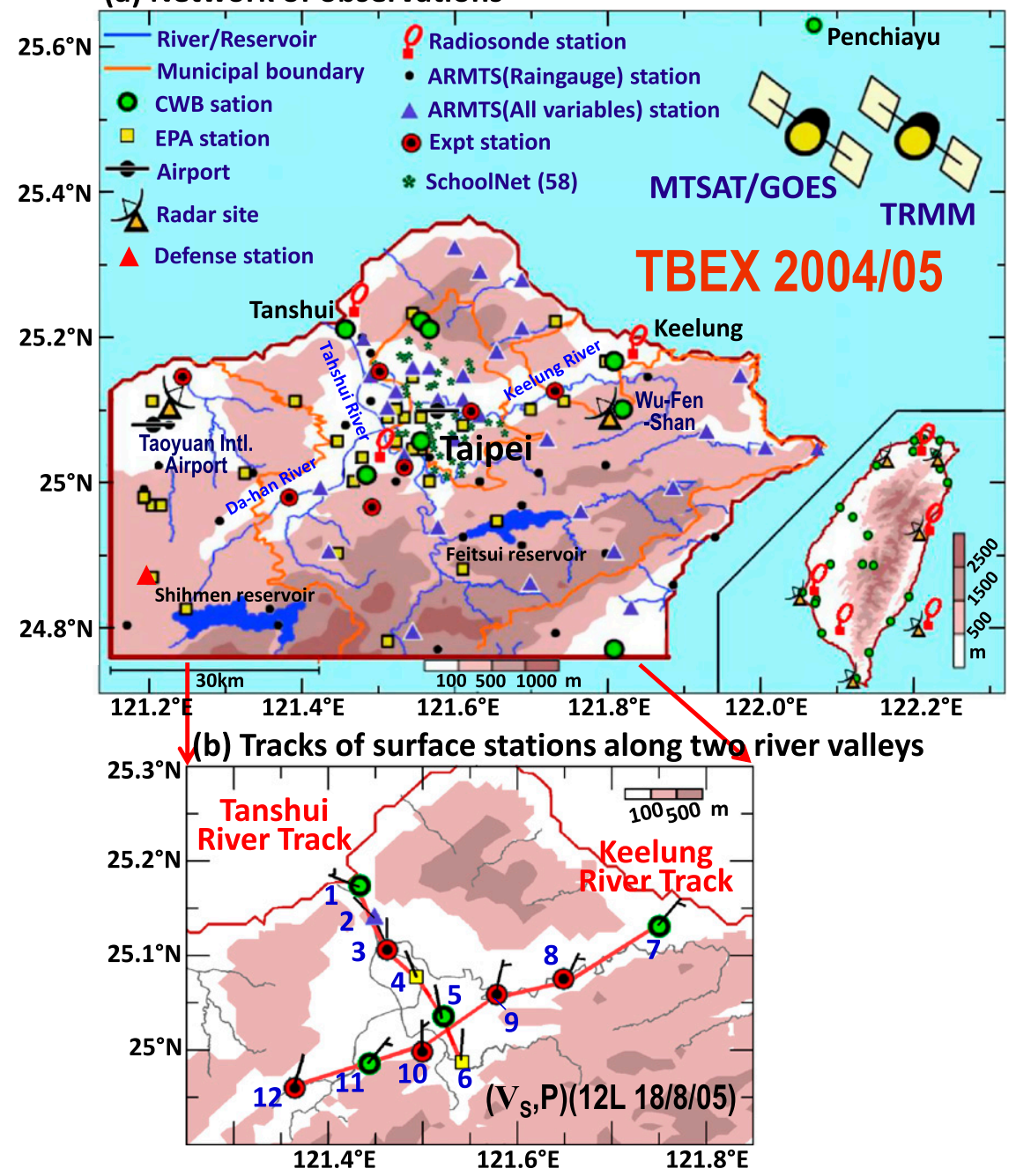

FIG. 2. Observational network used for TBEX during the summers of 2004 and 2005. (a) Surface and radiosonde stations, radars, and satellites provided by different agencies and supplemented by seven TBEX AWOS and two mobile radiosonde stations at Tanshui and Keelung. Networks for radiosonde, radar, and WMO surface stations in Taiwan are shown in the small panel in the bottom-right corner. (b) Two tracks of surface stations connected by red lines along the Taishui (1-6) and Keelung (7-12) River valleys. Time series of meteorological variables measured at these stations will be used to depict diurnal variations of meteorological conditions along these two river valleys. Surface winds measured at 1500 LST 28 Jul 2005 are displayed to illustrate the sea breezes along these valleys. The topography $(\mathrm{m})$ is included in each panel.

2) Automatic Rainfall and Telemetry Systems (ARMTS) In 1993, 400 ARMTS stations were established by CWB across Taiwan (Chen et al. 1999).

3) Radiosonde stations-Two additional mobile stations were added to supplement the Taipei soundings [World Meteorological Organization (WMO) identifier 46692] and were deployed to Tanshui (by the National Defense University) and Keelung (by the Navy Weather Forecast Center). This network of radiosonde observations is used to monitor the consistency of upper-level flows across the basin.
Sample soundings of this radiosonde network can be found in the supplemental material for this paper (supplement 1).

4) Radar observations-Radar observations at the Taoyuan International Airport and Wu-Fen Shan, part of the Taiwan Doppler weather radar network, are included to depict the evaluation of convection/ rainfall associated with thunderstorms.

5) Satellite observations-Rainfall distributions over the Taipei basin were depicted by the Tropical Rainfall Measuring Mission (TRMM) rainfall data 
(Huffman and Bolvin 2012), supplemented with the rainfall proxy calibrated with the infrared (IR) measurements by the Multifunctional Transport Satellite (MTSAT) and Geostationary Operational Environmental Satellite-9 (GOES-9) (Faller 2005; Clark 1983) over the southeastern part of the Taipei basin.

6) Initial analysis of the National Centers for Environmental Prediction Global Forecast System (GFS) The synoptic environment of the Taipei TS activity is analyzed and depicted with the GFS initial analysis (Kanamitsu et al. 1991; Yang et al. 2006).

\section{b. Identification of land-sea breezes with and without thunderstorms within the Taipei basin}

Although summer is a dry season in northern Taiwan, rain is still produced by afternoon thunderstorms and other weather systems (e.g., fronts and tropical cyclones; Chen et al. 1999). Using the enhanced mesonet supplemented by the Global Merged IR Brightness Temperature data (Janowiak et al. 2001), new rainfall estimation over this basin (supplement 2 of the supplemental material) is adopted. All TS days for the 2004 and 2005 summers are identified using the following criteria:

1) As indicated in the IR image of MTSAT/GOES-9 and distribution of TRMM precipitation radar data, the Taipei basin should be cloud/rainfall free in the morning but both cloud and TS rainfall should clearly appear in the afternoon.

2) Sea breezes are defined as the inbound surface winds along the two river valleys at about 1000 LST, while land breezes are defined as the outbound surface winds along these two valleys after the thunderstorm rain falls in the TS cases.

3) The maximum rainfall rate of thunderstorms within the Taipei basin should be $\geq 10 \mathrm{~mm} \mathrm{~h}^{-1}$.

4) Any day with rainfall produced by spring rainstorms, fronts, or tropical cyclones should be excluded. (The exclusion of these days is discussed further in supplement 3 of the supplemental material.)

5) Monsoon southwesterlies ( $\geq 5 \mathrm{kt}$, where $1 \mathrm{kt}=$ $0.51 \mathrm{~m} \mathrm{~s}^{-1}$ ) appear between 850 and $500 \mathrm{hPa}$ in the 0000 UTC sounding at Taipei.

Within the diurnal variation context, special salient features of the thunderstorm activity are illustrated against the no-thunderstorm (no-TS) days with SB and clear sky identified by using the following criteria:

1) no cumulus convection/rainfall occurs in northern Taiwan from early morning to midnight;

2) sea breezes appear after noontime but transform into land breezes immediately after sunset;
3) thunderstorm activity is absent in the Taipei basin;

4) as revealed by the Japan Meteorological Agency (JMA) surface analysis map and the 850-hPa streamline chart superimposed with IR images, a wellorganized east-west-oriented ridgeline from east China to the East China Sea appears north of Taiwan; and

5) easterlies/southeasterlies ( $\geq 5 \mathrm{kt})$ appear between 850 and $500 \mathrm{hPa}$ in the 0000 UTC sounding at Taipei.

In addition to the weather conditions identified as TS and no-TS conditions, other weather systems/conditions are also identified. Because they are not a major concern of the present study, their identifications are included in supplement 3 . The daily rainfall amounts produced inside the Taipei basin by different weather conditions/systems are marked with different acronyms and symbols in Fig. 3, including no-TS days. The East Asian summer monsoon undergoes two life cycles-the active and revival phases-separated by a break (Chen et al. 2004). Spring rainstorms, afternoon thunderstorms, and fronts produce major rainfall during the active phase in southern Taiwan, while rainfall during the breakrevival phase is generated by afternoon thunderstorms and tropical cyclones in northern Taiwan. The breakrevival phase covers the period 15 June-31 August (77 days). ${ }^{1}$ For this period, about $75 \%$ of the rainfall in the Taipei basin during the summers of 2004 and 2005 is produced by afternoon thunderstorms.

Fourteen TS days and 16 no-TS days were identified during summer 2004, and 18 TS days and 17 no-TS days were identified during summer 2005 inside the Taipei basin (Fig. 3). A noteworthy feature of the TS occurrence frequency emerges from the rainfall histograms. The TS occurrence frequency during summer 2005 followed the southeast East Asian monsoon life cycles well, but it did not during summer 2004. A typical no-TS (with SB and clear sky) day (28 July 2005) will be used to depict the life cycle of the land-sea breeze along the two river valleys. Special attention will be paid to the mountain effect surrounding the basin on this land-sea-breeze life cycle. The impact of afternoon thunderstorms on the land-sea-breeze life cycle will be illustrated through the change in the diurnal variation of the basin's environmental conditions, coupled with the life cycle of the thunderstorm's cumulus convection/rainfall.

\footnotetext{
${ }^{1}$ This time period is determined by two factors: 1$)$ the life cycle of the East Asian monsoon depicted by Chen et al. (2004) and 2) the averaged first day of thunderstorms occurring in the Taipei basin in June (for 1993-2004) close to the monsoon break. The details of this timing determination are posted in supplement 4 of the supplemental material.
} 


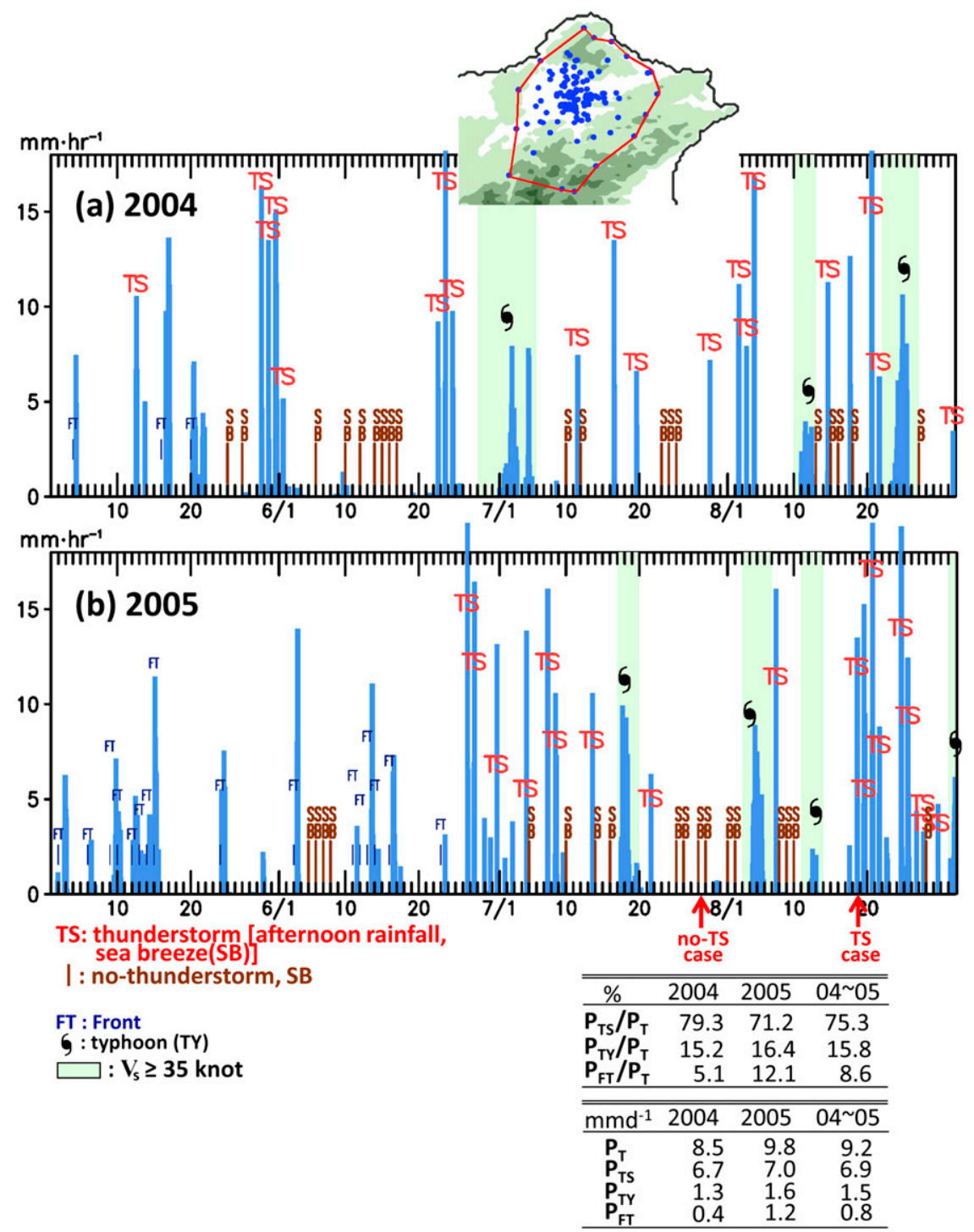

FIG. 3. Histograms of the area-averaged rainfall over the Taipei basin estimated with rain gauges (blue dots) encircled by a red line near the top center of (a). Different weather conditions/systems are marked by different acronyms and symbols (explained at the bottom of the figure) in the rainfall histograms. The rainfall histograms are for the summers of (a) 2004 and (b) 2005. Rainfall produced by TSs, tropical cyclones (TYs), and fronts (FTs), and their ratios with total $(\mathrm{T})$ rainfall are shown in the bottom-right tables.

\section{Synoptic analysis of a nonthunderstorm case (28 July 2005)}

\section{a. Synoptic environment}

Shown by the JMA surface analysis map at 0000 UTC [0800 local standard time (LST)] 28 July 2005 (Fig. 4a), Taiwan is surrounded by three major synoptic elements: 1 ) a surface cyclone centered at the northern South China Sea, 2) the well-organized North Pacific Ocean anticyclone, and 3) a front parallel to the Yangtze River. Exhibited in the $850-\mathrm{hPa}$ streamline chart superimposed with the MTSAT IR image (Fig. 4b) is an east-west-oriented ridgeline of the North Pacific anticyclone north of Taiwan. Although Taiwan is located downstream of the monsoon southerlies, this synoptic environment does not transport sufficient moisture to produce clouds there. The 0000 UTC upper-air sounding at Taipei (Fig. 4c) substantiates this inference. A shallow weak inversion layer appears below $850 \mathrm{hPa}$. The surface dewpoint depression $\Delta T_{d}$ is about $2 \mathrm{~K}$; it is $5-7 \mathrm{~K}$ above $700 \mathrm{hPa}$. 


\section{$28 / 07 / 2005$}

(a) JMA surface synoptic map (00UTC)

(d) JMA surface synoptic map (06UTC)
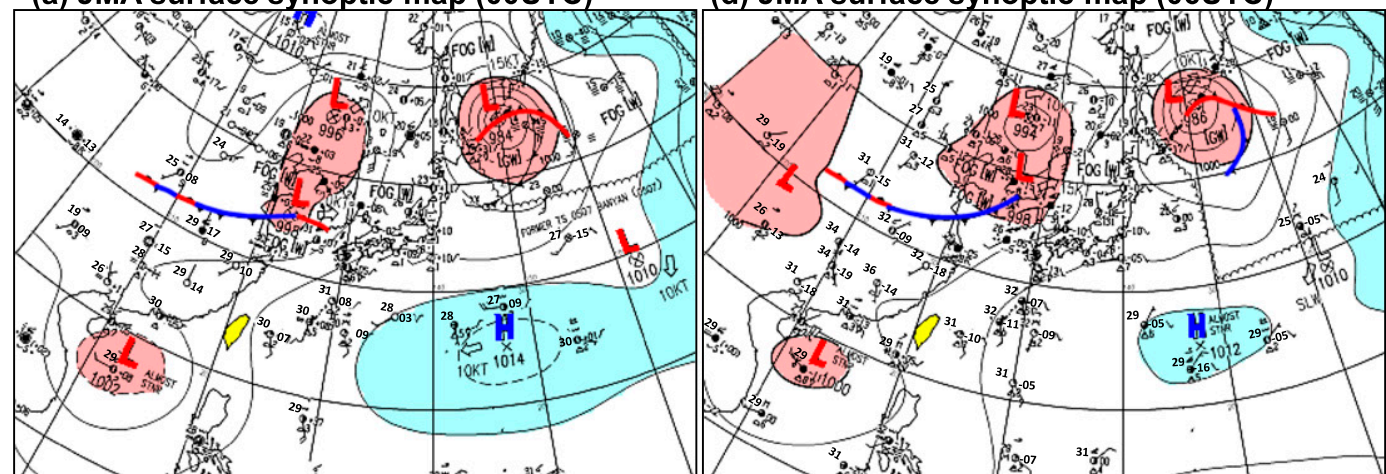

(b) [V(850hPa), IR](00UTC)

(e) [V(850hPa), IR](06UTC)

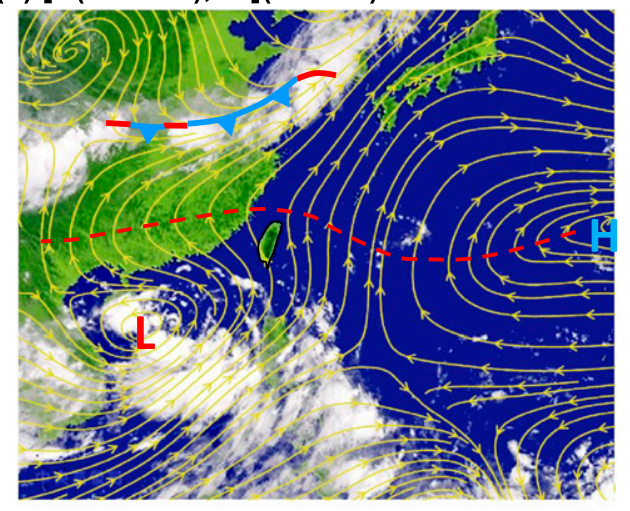

(c) Sounding(Taipei 46692)(00UTC)
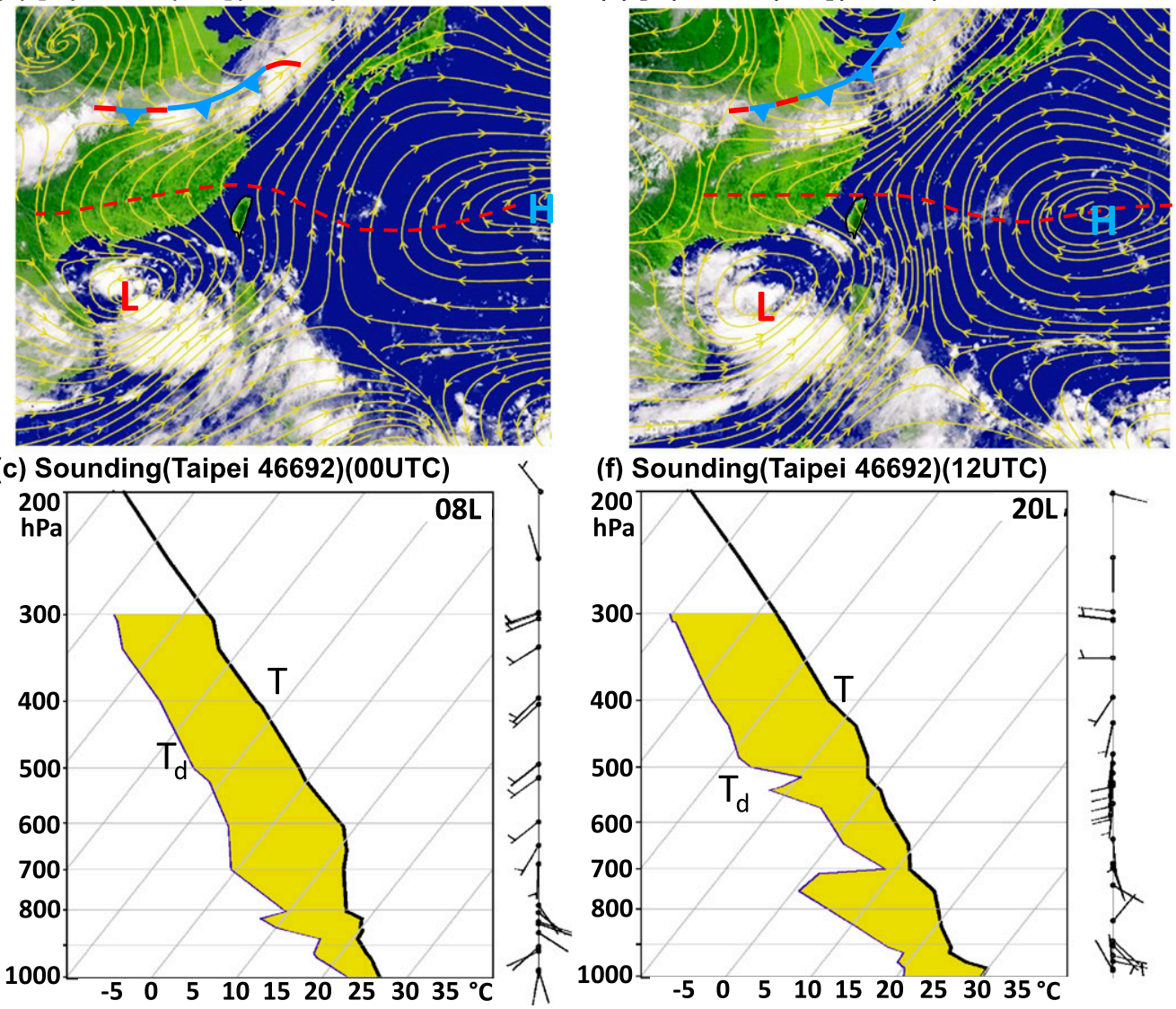

(f) Sounding(Taipei 46692)(12UTC)

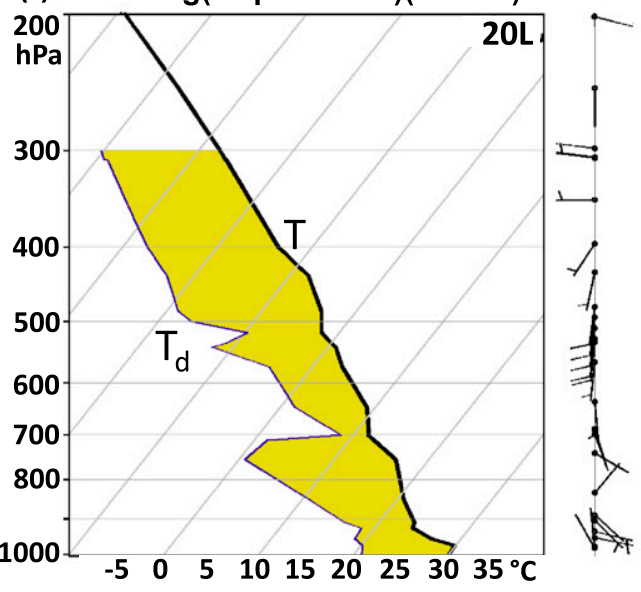

FIG. 4. Synoptic conditions on a no-TS day with sea breezes under clear skies at (left) 0000 and (right) 0600 UTC 28 Jul 2005 and with the upper-air soundings at 1200 UTC: (a),(d) JMA surface analysis maps; (b),(e) 850-hPa streamline charts superimposed with cloud images, fronts, and ridgelines (dashed red line); and (c),(f) upperair soundings of $T$ and $T_{d}$ at Taipei (WMO 46692). Low (L) and high (H) symbols are added in (a),(b),(d), and $(\mathrm{e})$.

The 700-300-hPa upper-air flows are southwesterly/ southerly. Six hours later at 0600 UTC (1400 LST), the synoptic conditions (Fig. 4d) have not changed significantly. The northeast Asian trough moves slightly closer to Japan, so the southwesterlies cross Japan and the southeasterlies east of Taiwan intensify slightly (Fig. 4e).
Daytime heating raises the Taipei surface temperature to $30^{\circ} \mathrm{C}$ (Fig. $4 \mathrm{f}$ ) and makes the surface air drier with $\Delta T_{d} \sim 5 \mathrm{~K}$. A second weak inversion appears slightly below $500 \mathrm{hPa}$, where the airflow is dominated by southerlies. Above $500 \mathrm{hPa}$, the airflow becomes drier with $\Delta T_{d} \sim 7 \mathrm{~K}$ and also becomes southwesterly/westerly. 


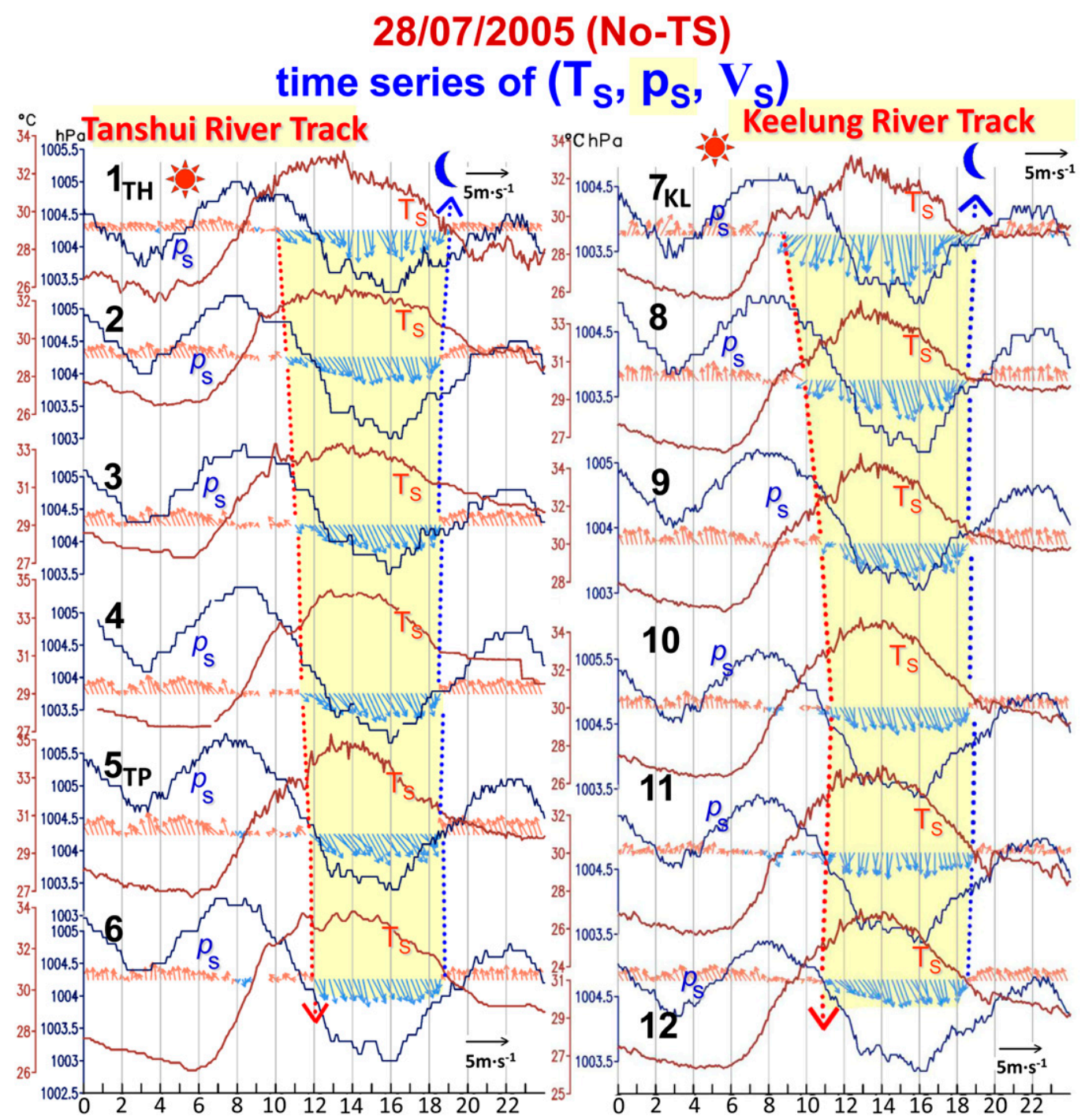

FIG. 5. Time series of $T_{s}, p_{s}$, and $\mathbf{V}_{s}$ at stations along the Tanshui (1-6) and Keelung (7-12) River valleys for a noTS, SB, and clear-sky day (28 Jul 2005). Timings of sunrise and sunset are noted by symbols for the sun and moon, respectively. The SB onset and cessation times for all stations along each river valley are connected by red and blue dotted lines, respectively.

Revealed by the inversion layer, the lower-tropospheric thermal structure shows a $T_{d}$ increase below $700 \mathrm{hPa}$, so no cumulus clouds appear at Taipei (Fig. 4e).

\section{b. Alternation of the no-thunderstorm land and sea breezes}

The Taipei basin-open sea airmass exchange is caused by the alternation between the daytime sea breeze and the nighttime-early morning land breeze along the two river valleys. This ventilation mechanism is illustrated with station time series $\left(T_{s}, p_{s}, \mathbf{V}_{s}\right)$ (Fig. 5) on 28 July 2005 along these river valleys (Fig. 2b).
The sun rises at 0519 LST and sets at 1841 LST; the daytime radiative heating and the nighttime radiative cooling cover $12 \mathrm{~h}, 22 \mathrm{~min}$ and $11 \mathrm{~h}, 38 \mathrm{~min}$, respectively. Dominated by a diurnal cycle, $T_{s}$ reaches its minimum at different stations during 0400-0600 LST and its maximum during $1200-1400 \mathrm{LST}$. It takes only $8 \mathrm{~h}$ for $T_{s}$ to rise from its minimum to its maximum, but $16 \mathrm{~h}$ to cool back to its minimum. Other physical processes cause this asymmetry between the heating and cooling rates. Differing from the $T_{s}$ diurnal variation, $p_{s}$ exhibits a clear semidiurnal variation, as observed by previous studies (e.g., Simpson 1994; Chen et al. 1998). Thus, an intriguing relationship between $p_{s}$, and $T_{s}$ emerges_-both variables 
TABLE 1. Three phases of the clear-sky, no-TS land-sea breezes (28 Jul 2005) used to depict the temporal evolution for the $p_{s}, T_{s}, \mathrm{RH}_{s}$, and $\mathbf{V}_{s}$ spatial structure.

\begin{tabular}{llll}
\hline \hline Local time (LST) & \multicolumn{1}{c}{0600} & \multicolumn{1}{c}{1500} & \multicolumn{1}{c}{} \\
\hline Salient features of & $\Delta p_{s}>0$ & $\Delta p_{s}<0$ & $\Delta p_{s}>0$ \\
diurnal variation & $T_{s}:$ min & $T_{s}:$ max & $T_{s}:$ min \\
& $\mathrm{RH}_{s}:$ large/moist & $\mathrm{RH}_{s}:$ small/dry & \multicolumn{2}{c}{ LB $H_{s}:$ large/moist } \\
& $\mathrm{LB}$ & $\mathrm{SB}$ & Sunset at 1814 \\
\hline
\end{tabular}

vary oppositely only between the $p_{s}$ morning maximum (0800 LST) and its late-night maximum (2200 LST), but vary coherently over the remainder of the day $(2200$ 0800 LST).

The alternation between the LB (brown vectors) and $\mathrm{SB}$ (blue vectors) along these two river valleys, accompanied by an LB-SB front (supplement 5 of the supplemental material), is also reflected by the relationship between $p_{s}$ and $T_{s}$. When $p_{s}$ reaches its morning maximum $(\sim 0800 \mathrm{LST})$, the $p_{s}$ tendency $\partial p_{s} / \partial t \simeq 0$, so a persistent flow is no longer maintained. Following the LB cessation, a transition period (about 1.5-6h) of a weak, chaotic flow appears along the coast of the Gulf of Mexico, as observed by Hill et al. (2010), before $T_{s}$ reaches it daytime maximum. After the $p_{s}$ morning maximum, the strong negative $\partial p_{s} / \partial t$ and positive $\partial T_{s} / \partial t$ during this $p_{s}$ decline phase facilitate the intrusion of SB. The SB onset occurs at 1000 LST at Tanshui and 0900 LST at Keelung but is delayed about $2-3 \mathrm{~h}$ at stations 6 and 12 close to the mountain slopes. SB cessation-LB onset occurs at sunset (1841 LST), when $\partial p_{s} / \partial t>0$ and $\partial T_{s} / \partial t<0$. The radiative cooling over the mountains surrounding the Taipei basin that cause a down-valley drainage flow, seems to be an effective means to triggering the LB onset earlier than at the coast, as Case et al. (2005) observed at the Florida Spaceport.

The diurnal variation of surface relative humidity $\mathrm{RH}_{s}$ is generally opposite $T_{s}$ (Djurić 1994; Lawrence 2005). Compared with the corresponding $T_{s}$, a clear distinction between the SB (daytime) and LB (late eveningmorning) regime emerges from $\mathrm{RH}_{s}$ variations along the two river valleys (supplement 6 of the supplemental material). The transitions between these two $\mathrm{RH}_{s}$ regimes are characterized by a gradually drying LB-SB transition after sunrise and an abrupt moistening SB-LB transition at sunset.

\section{c. Diurnal variation of the basin environment associated with land-sea breezes}

As seen from the time series for $\left(\mathbf{V}_{s}, T_{s}, p_{s}, \mathrm{RH}_{s}\right)$, the basin environment undergoes some diurnal variation. Horizontal charts depict this variation for these variables and $\Delta p_{s}$ in three phases of the basin's land-sea breezes (Table 1) in Fig. 6: two LB (at 0600 and 2100 LST) and one SB (at 1500 LST) regimes. Note that $\Delta p_{s}=p_{s}(t+15 \mathrm{~min})-p_{s}(t-15 \mathrm{~min})$ at a specified time, $t$. Characteristic changes of these variables are summarized below.

\section{1) LAND-BREEZE REGIMES AT 0600 AND 2100 LST}

The centers of both $p_{s}$ (Figs. 6a,c) and $T_{s}$ (Figs. 6d,f) almost coincide over the basin's center, which is in the southwestern Taipei district. Indicated by $\Delta p_{s}>0$ (Figs. $6 \mathrm{a}, \mathrm{c}), p_{s}$ increases inside the basin at 0600 and $2100 \mathrm{LST}$, consistent with station $p_{s}$ time series along the river valleys (Fig. 5). The $\Delta p_{s}>0$ center (the southwestern Taipei district) is larger than its surroundings, so the land breezes (red wind barbs) are maintained by the downgradient $p_{s}$ and $\Delta p_{s}$ from their centers. At 0600 LST (after $2100 \mathrm{LST}$ ), $T_{s}$ reaches its morning (nighttime) minima. Despite its minimum times, $T_{s}$ in the southwestern Taipei district is about $2-3 \mathrm{~K}$ higher than at Tanshui and Keelung, the two river exit stations. Consistent with the Taipei urban area, this $T_{s}$ center is a reflection of the urban heat island (UHI) effect with a low $\mathrm{RH}_{\mathrm{s}}$ center (Figs. 6d,f). As can be seen from the $\left(p_{s}, T_{s}\right.$, $\mathbf{V}_{s}, \mathrm{RH}_{s}$ ) spatial distributions and their relationships with the land breezes, the air mass with larger $p_{s}$ and $T_{s}$ and lower $\mathrm{RH}_{s}$ is transported out of the basin by the land breezes.

\section{2) SEA-BREEZE REgIME AT 1500 LST}

Coincident with the basin's center at 1500 LST (Fig. $6 \mathrm{~b})$, the $p_{s}$ center has a magnitude larger than its surrounding areas, even though it is lower than the LB regime (Figs. 6a,c). The $\left(\Delta p_{s}<0\right)$ center also coincides with the $p_{s}$ center, but its decreasing rate is larger than its surrounding areas. However, this slight upgradient $p_{s}$ is overpowered by the downgradient $\Delta p_{s}$ to maintain the SB flow. The $T_{s}$ center, coincident with the $p_{s}$ center, is warmer than its surrounding areas as in the LB regime This upgradient $T_{s}$ distribution facilitates an ascending motion coupled with the incoming SB flow. The updraft over the warm $T_{s}$ center should reduce $\mathrm{RH}_{s}$ (to $50 \%$ ) to maintain a downgradient $\mathrm{RH}_{\mathrm{s}}$ distribution. The spatial relationship between $\left(p_{s}, \Delta p_{s}, T_{s}, \mathrm{RH}_{s}\right)$ and the sea breezes indicates the moist air with larger $p_{s}$ and $T_{s}$ is 


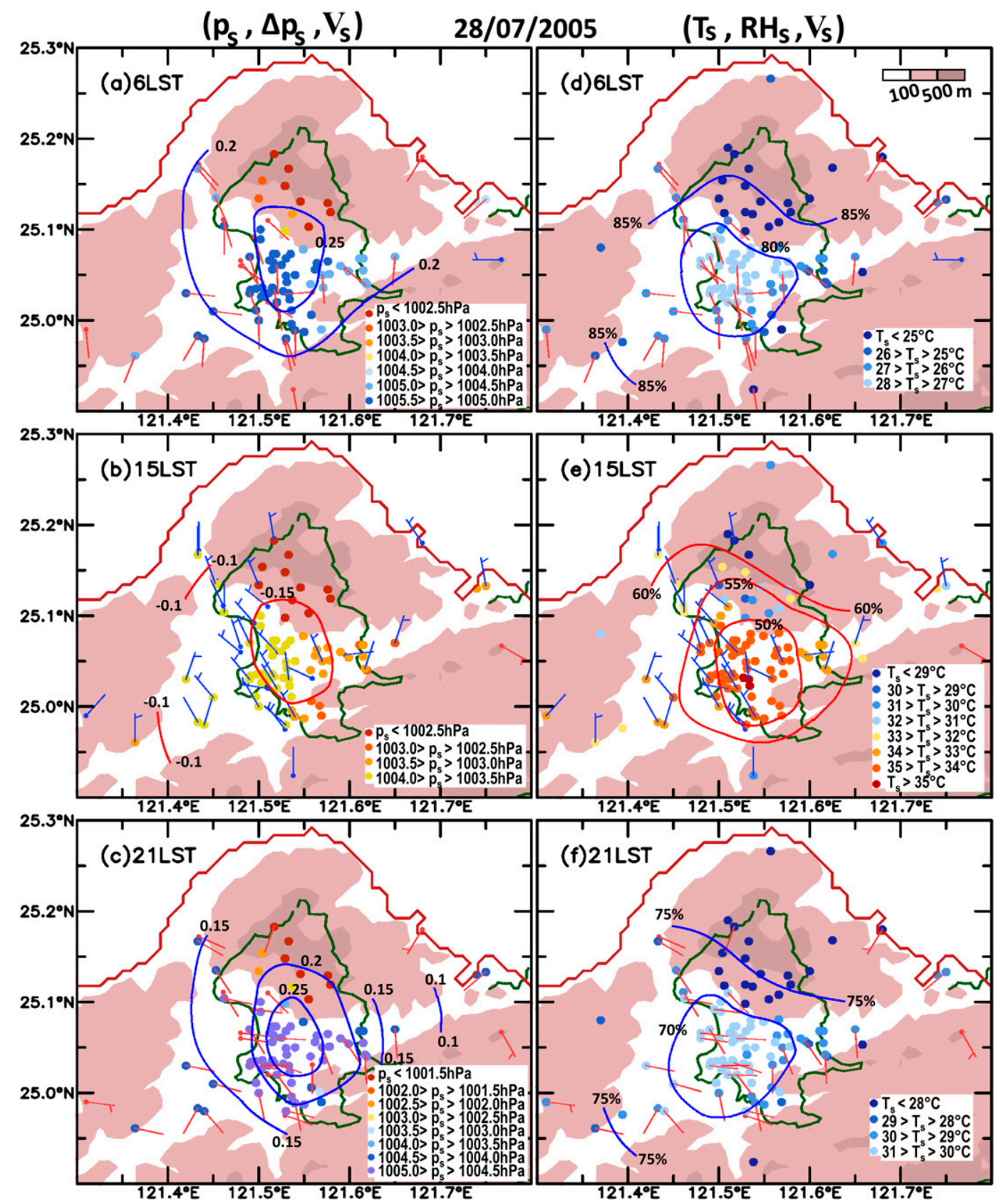

FIG. 6. Spatial distributions of (left) $p_{s}, \Delta p_{s}$, and $\mathbf{V}_{s}$ and (right) $T_{s}, \mathrm{RH}_{s}$, and $\mathbf{V}_{s}$ on $28 \mathrm{Jul} 2005$ illustrated with measurements from surface stations during three different phases of the $p_{s}$ diurnal variation: 0600 LST (early morning; $\Delta p_{s}>0$ ), 1500 LST (afternoon; $\Delta p_{s}<0$ ), and 2100 LST (late night; $\Delta p_{s}>0$ ). Station measurements for surface pressure $\left(p_{s}\right)$ and temperature $\left(T_{s}\right)$ are indicated by different-colored dots scaled in the bottom-right corner of each panel. Surface pressure tendency, $\Delta p_{s}\left[=p_{s}(t+15 \mathrm{~min})-p_{s}(t-15 \mathrm{~min})\right]$, is contoured in each left panel for $\Delta p_{s}>0(<0)$ with blue (red) lines with an interval of $5 \times 10^{-2} \mathrm{hPa}(30 \mathrm{~min})^{-1}$. In the right panels, $\mathrm{RH}_{s} \geq 70 \%$ $(\leq 60 \%)$ is contoured by blue (red) lines with an interval of $5 \%$. Following the convention of the surface synoptic chart, the land (sea) breezes are indicated by wind vectors measured at the surface stations with red (blue) wind barbs, whose speeds are defined by WMO convention. The topography $(\mathrm{m})$ is indicated with pink shading. The Taipei district is encircled with a green line. 


\section{$18 / 08 / 2005$}

(a) JMA surface synoptic map (00UTC)

(d) JMA surface synoptic map (06UTC)

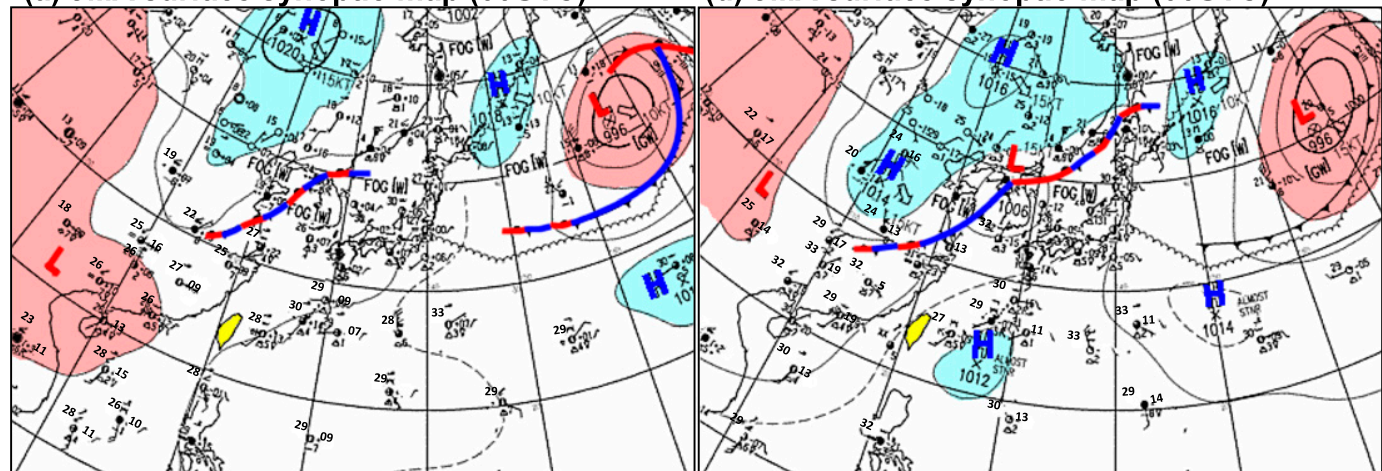

(b) $[\mathrm{V}(850 \mathrm{hPa}), \mathrm{IR}](00 \mathrm{UTC})$

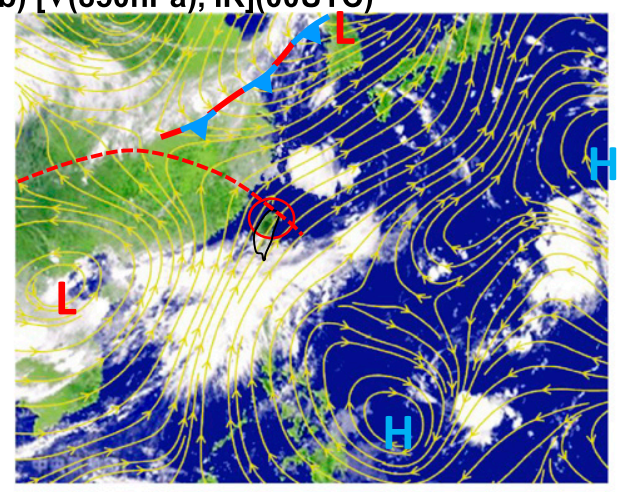

(c) Sounding(Taipei 46692)(00UTC)

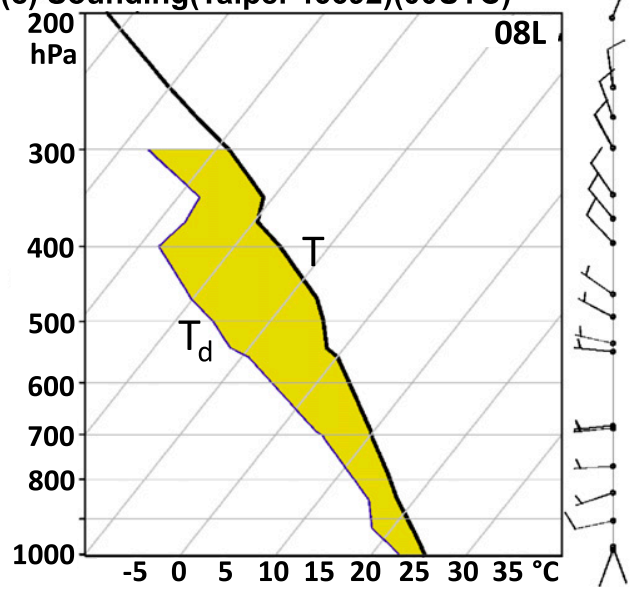

(e) [V(850hPa)(06UTC), IR(07UTC)]
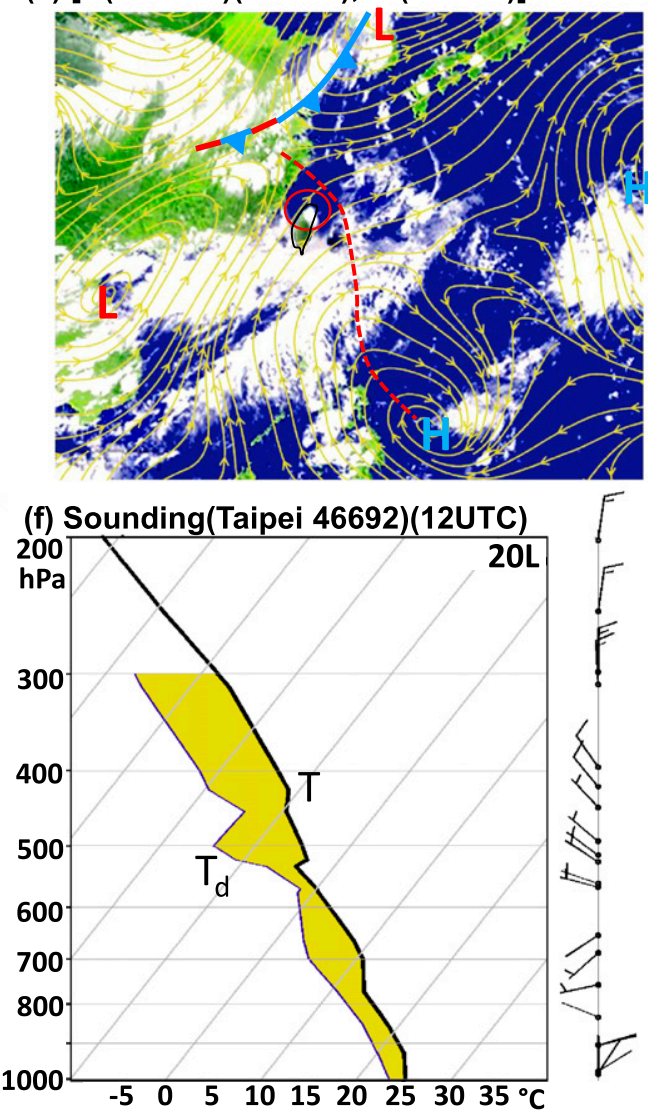

FIG. 7. As in Fig. 4, but for a TS day (18 Aug 2005).

transported by the SB flow into the basin. Zhong et al. (1991) and Zhong and Takle (1992) observed the landsea-breeze circulation in the Kennedy Space CenterCape Canaveral area, as modified by the heterogeneous heating of land and water bodies there. By contrast, the Taipei basin-open sea air ventilation, established by the LB (late evening) and SB (daytime) alternation, is regulated by the nighttime radiative cooling and the daytime radiative heating around this basin.

\section{Synoptic analysis of a thunderstorm case (18 August 2005)}

\section{a. Synoptic environment}

The three basic synoptic elements of the no-TS day (Fig. 4a) in eastern/Southeast Asia are not well visible in the JMA surface analysis map (Fig. 7a) at 0000 UTC (0800 LST) 18 August 2005 in the vicinity of Taiwan. However, these synoptic elements become discernible on the 


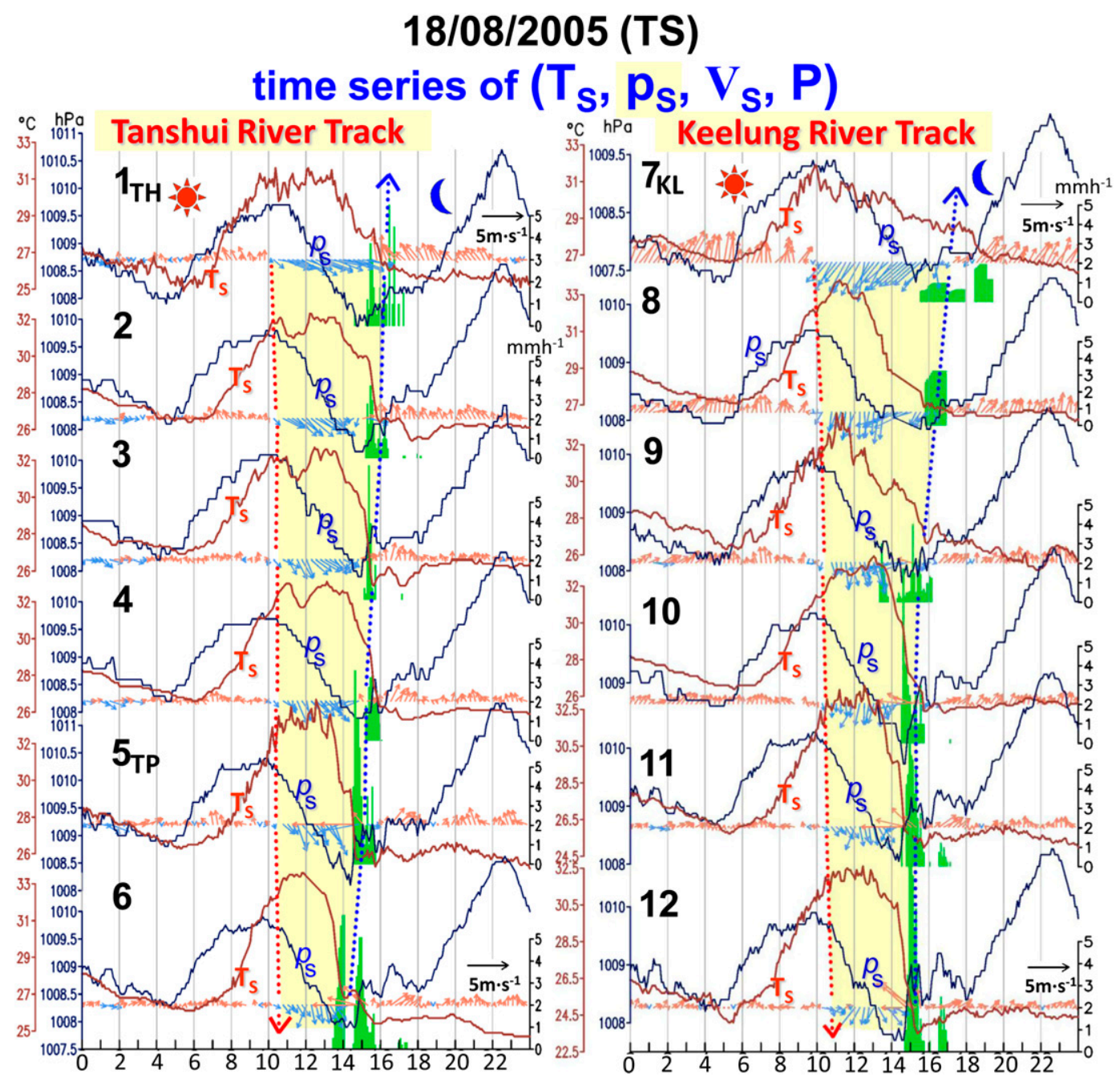

FIG. 8. As in Fig. 5, but for a TS day (18 Aug 2005). The TS rainfall is indicated by a green histogram.

850-hPa streamline chart superimposed with the MTSAT IR imagery (Fig. 7b): a cyclonic low system centered over northern Vietnam and an anticyclonic high located in the Philippine Sea. Juxtaposed with this low-high dipole is a large, deep convective area over the northern South China Sea. North of Taiwan, an east-west-oriented ridge extends from south China to the East China Sea, and a front stretches from the Yangtze River valley to North Korea. Because the ridgeline maintains a cloudfree zone, no morning convection appears in northern Taiwan.

The morning clear sky observed at Taipei is supported by the Taipei upper-air sounding (Fig. 7c): $2.5<$ $\Delta T_{d}<5.5 \mathrm{~K}$ below $700 \mathrm{hPa}$ and $\Delta T_{d} \sim 10 \mathrm{~K}$ above. The moist westerly-southwesterly flow below $500 \mathrm{hPa}$, part of the monsoon trough in southern/Southeast Asia (supplement 7 in the supplemental material), yields to the drier northwesterly flow above. The ridgeline north of Taiwan is a downward penetration of the Tibetan high's eastern branch. The synoptic conditions do not show significant changes $6 \mathrm{~h}$ later (Fig. 7), except for a slight southward migration of the trough line across South Korea (Fig. 7e). The cloud-free zone in south China still exists, but convection appears over northern Taiwan, as reflected by small $\Delta T_{d}<2.5 \mathrm{~K}$ up to $550 \mathrm{hPa}$ and $<5 \mathrm{~K}$ above $500 \mathrm{hPa}$ (Fig. 7f). Because the flow pattern resembles that at 0000 UTC, the lower-tropospheric warm-moist southwesterly flow facilitates convection over the Taipei basin.

\section{b. Alternation of the land-sea breeze by thunderstorm}

The TS day of 18 August 2005 is selected to illustrate the diurnal variations of the basin environment and the LB-SB circulation affected by afternoon thunderstorms. The impacts (Fig. 8) are highlighted below. 
TABLE 2. Occurrence timing (LST) of $p_{s}(\mathrm{TS})$ and $p_{s}$ (no-TS) minima and maxima in Figs. 4 and 7, respectively.

\begin{tabular}{lcccc}
\hline \hline & $\begin{array}{c}\text { Early } \\
\text { morning } \\
\min \end{array}$ & $\begin{array}{c}\text { Daytime } \\
\max \end{array}$ & $\begin{array}{c}\text { Major } \\
\text { daytime } \\
\min \end{array}$ & $\begin{array}{c}\text { Late } \\
\text { night } \\
\max \end{array}$ \\
\hline$p_{s}(\mathrm{no}-\mathrm{TS})$ & $0300-0400$ & 0800 & 1600 & 2200 \\
$p_{s}(\mathrm{TS})$ & $0400-0500$ & 1000 & $1400-1500$ & 2300 \\
& \multicolumn{2}{c}{ Sunrise } & \multicolumn{2}{c}{ Sunset } \\
\hline \multicolumn{4}{c}{$r$}
\end{tabular}

1) After sunrise (0529 LST), the daytime radiative heating raises $T_{s}(\mathrm{TS})^{2}$ from its early morning minimum to its maximum (1000-1200 LST), about $2 \mathrm{~h}$ earlier than the no-TS day. When the thunderstorm rain falls at $1200-1300 \mathrm{LST}, T_{s}(\mathrm{TS})$ drops quickly to its minimum at about $1400-1600$ LST $\left[T_{s}\right.$ (no-TS) maximum time], and levels of within $1-2 \mathrm{~h}$ to reach a quasi-constant state overnight.

2) The $p_{s}(\mathrm{TS})$ diurnal variation exhibits a pronounced semidiurnal variation. The early morning $p_{s}(\mathrm{TS})$ minimum (0400-0500 LST) is $1-2 \mathrm{~h}$ behind the $p_{s}\left(\right.$ no-TS) minimum, but $p_{s}(\mathrm{TS})$ reaches its daytime maximum at $1000 \mathrm{LST}$. The daytime $p_{s}$ drops to its minimum just before the TS rainfall, but follows with a $p_{s}$ jump when the TS rain falls. A mesohigh south of the LB front, formed by this $p_{s}$ jump, persists for $3-6 \mathrm{~h}$ until sunset. This $p_{s}$ (TS) rises again at sunset and reaches its second maximum (2300 LST) an hour behind the second maximum of $p_{s}$ (no-TS). The differences between the $p_{s}\left(\right.$ no-TS) and $p_{s}(\mathrm{TS})$ variations are summarized in Table 2.

3) The LB (TS) regime is weak along the Tanshui River valley before the SB (TS) onset. This onset (10001100 LST) accompanied by the SB front occurs as soon as $p_{s}$ (TS) reaches its daytime maximum and $\Delta p_{s}(\mathrm{TS})<0$ starts. The SB (TS) ceases when the TS rain falls, about $2-5 \mathrm{~h}$ ahead of sunset. Coupled with a LB front, the LB (TS) onset appears immediately after the SB (TS) cessation, but occurs earlier at stations close to the mountain slopes.

4) As inferred from the 0000 UTC sounding, the lowertropospheric $\Delta T_{d}(\mathrm{TS})$ is smaller than $\Delta T_{d}$ (no-TS). When $T_{s}$ (TS) reaches its morning minimum after sunrise, the $\mathrm{RH}_{s}(\mathrm{TS})$ exhibits a mild overshooting (supplement 6). During the LB-SB transition at about 1000-1200 LST, the $\mathrm{RH}_{s}(\mathrm{TS})$ decreases to its daytime minimum. After the noon hour, the $\mathrm{RH}_{s}(\mathrm{TS})$ undergoes an abrupt increase, opposite to

\footnotetext{
${ }^{2}$ For convenience, any variable () of TS and no-TS days will be followed by these two parenthetical acronyms.
}

the drastic drop of $T_{s}(\mathrm{TS})$, close to the occurrence of TS rainfall. Right after the TS rainfall, the $\mathrm{RH}_{s}(\mathrm{TS})$ rises to exceed $90 \%$ at all stations.

Comparison of the $\left(T_{s}, p_{s}, \mathbf{V}_{s}, P\right)$ time series for TS (Fig. 8) and no-TS (Fig. 5) days reveals a significant impact of afternoon thunderstorms on the land-seabreeze life cycle along the two river valleys: the shortening of the sea-breeze duration and the formation of a mesohigh. This impact is highlighted in Table 3.

\section{c. Diurnal variation of the basin environment affected by afternoon thunderstorms}

The diurnal variation of the TS basin environment changed by afternoon thunderstorms is spatially illustrated in Fig. 9.

\section{1) LAND BREEZES IN THE EARLY MORNING (0600 LST)}

On the no-TS day (Fig. 6a), the $p_{s}$ (TS) center, located over the southwest Taipei district, coincides with the $\Delta p_{s}$ (TS) center (Fig. 9a). This downgradient $p_{s}(\mathrm{TS})$ and $\Delta p_{s}(\mathrm{TS})$ pattern maintains the LB flows along the two river valleys. Different from the no-TS day (Fig. 6d), $T_{s}(\mathrm{TS})$ in the southwest Taipei district becomes slightly cooler $(\sim 1 \mathrm{~K})$ than does the central Taipei district (Fig. $9 \mathrm{a})$. The $T_{s}$ (TS) distribution over the entire district exhibits a cold-warm-cold stratification in the southwestnortheast direction, while the $\mathrm{RH}_{s}(\mathrm{TS})$ shows an opposite pattern (Fig. 9d). The larger $\mathrm{RH}_{s}$ in the southwest district establishes a favorable environment for the development of afternoon thunderstorms.

\section{2) SUDDEN LAND-SEA-BREEZE TRANSITION WHEN THE AFTERNOON THUNDERSTORM RAIN FALLS (1500 LST)}

Inferred from the 3-km radar echo (supplement 8 of the supplemental material) in Fig. 10a, thunderstorm rainfall starts at 1400 LST over the mountain slope. For comparison with the no-TS days, the environmental conditions at 1500 LST (Figs. 9b,e) are shown: higher $p_{s}$, $\Delta p_{s}>0$, cooler $T_{s}$, and higher $\mathrm{RH}_{s}$ appear south of the front. This change leads to the land-sea-breeze transition.

\section{3) LAND BREEZES DURING LATE NIGHT (2100 LST)}

The downdraft and mesohigh formed by the TS rainfall enables this rainfall to spread outward from the central district to the surrounding mountains (Figs. 10e,f), and is accompanied by the outflow of the cooler and higher $\mathrm{RH}_{s}$ air mass (Fig. 9f). Thus, the high $p_{s}$ and 
TABLE 3. As in Table 1, but for the TS land-sea breezes (18 Aug 2004).

\begin{tabular}{|c|c|c|c|}
\hline Local time (LST) & 0600 & 1500 & 2100 \\
\hline \multirow[t]{5}{*}{$\begin{array}{l}\text { Salient features of } \\
\text { diurnal variation }\end{array}$} & $\Delta p_{s}>0$ & $\begin{array}{c}\Delta p_{s}>0, \text { because of } \\
p_{s} \text { jump }(\sim 1 \mathrm{hPa}) \\
\text { caused by TS } \\
\text { rainfall }\end{array}$ & $\Delta p_{s}>0$ \\
\hline & $T_{s}: \min$ & $\begin{array}{l}T_{s}: \text { min when } \mathrm{TS} \\
\text { rain falls }\end{array}$ & $\begin{array}{c}T_{s}: \text { levels off with a } \\
\text { nighttime min }\end{array}$ \\
\hline & $\begin{array}{l}\mathrm{RH}_{s}: \text { a mild } \mathrm{RH}_{\mathbf{s}} \\
\text { overshooting at } \\
0600 \text { LST }\end{array}$ & $\mathrm{RH}_{s}:$ drastic jumps & $\begin{array}{l}\mathrm{RH}_{s} \text { : levels off with a } \\
\text { nighttime max }\end{array}$ \\
\hline & $\begin{array}{l}\text { Weak LB: along the } \\
\text { Tanshui River valley }\end{array}$ & LB surge & Weak LB \\
\hline & \multicolumn{2}{|c|}{ Sunrise at 0519} & \\
\hline
\end{tabular}

$\Delta p_{s}>0$ zones also expand to cover the entire basin and lets the land breezes prevail along the two river valleys. During this stage, the southwestern basin is still highly moist $\left(\mathrm{RH}_{s}>90 \%\right)$.

The environmental change brought about by thunderstorms actually starts before the TS occurrence. The SB-LB transition is expedited by the mesohigh formation by the TS rainfall, which dissipates through its outward propagation to the surrounding mountains.

\section{d. Life cycle of afternoon thunderstorms in the Taipei basin}

The impact of the land-sea breeze and the basin environment is coupled with the thunderstorm life cycle. To obtain a geographic perspective of the 18 August 2008 afternoon thunderstorm development, the horizontal distributions of radar echoes every half hour during 1400-1600 LST are shown in Fig. 10. This thunderstorm life cycle is divided into three stages, which are discussed below.

\section{1) INITIAL STAGES}

As pointed out by Shepherd (2005), the rainfall enhancement on the downwind side of major cities is observed by a spaceborne precipitation radar system and coincident with the surface convergence/vertical motion on the leeward side of the UHI simulated by numerical studies. The vertical motion on the downwind side south of the Taipei UHI, added by the upslope flow of the cross-basin sea breeze, develops a favorable environment for convection/TS rainfall. The daytime radiative heating over the southern slopes triggers cumulus convection/TS rainfall at 14 LST (Fig. 10a). Minor convection also appears over the southwestern slopes and the northern tip of the Taipei district.

\section{2) Mature stage}

As revealed from the gradients of TS rainfall and radar echoes (Fig. 10c), a cold front forms across the large gradients of $p_{s}, \Delta p_{s}, T_{s}, \mathrm{RH}_{s}$, and $\mathbf{V}_{s}$ (Figs. 9b,e), north of the heavy TS rainfall area. A half-hour later, the TS convection-rainfall covers the entire basin along the northeast-southwest axis, extending from the northern tip of Taiwan all the way to the mountain slopes adjacent to the southwest tributary of the Keelung River and the mountains south of the Taipei district (Fig. 10d). A small convective cell also appears over the mountain slope southeast of the district.

\section{3) Dissipation Stage}

At $1600 \mathrm{LST}$, the north-south $T_{s}$ gradients across the central basin (supplement 9 in the supplemental material) and TS convection/rainfall diverge outward to the mountains/mountain slopes surrounding the basin in three directions: the northeast, southeast, and southwest (Fig. 10e). The central basin is mostly free of convection/rain with some light rain. Likely, the upward motion over the convection/TS rainfall areas surrounding the basin converges through the secondary circulation to form an aggregated downdraft over the central basin. Thus, a high pressure center is established by this downdraft, which consequently diverges the convection/ rainfall farther outward in the next hour (Fig. 9f) and eventually dissipates.

\section{Circulation statistics of land-sea breezes for all identified no-TS and TS days}

The land-sea breeze circulation and the impacts of the TS occurrence on it in the Taipei basin were illustrated with salient features emerging from the diurnal variations of the synoptic environment around the Taipei basin, and the meteorological conditions inside this basin for a no-TS and a TS day were presented in sections 3 and 4, respectively. It is important to determine whether salient features for these two cases presented are common to all identified days for each corresponding group. 


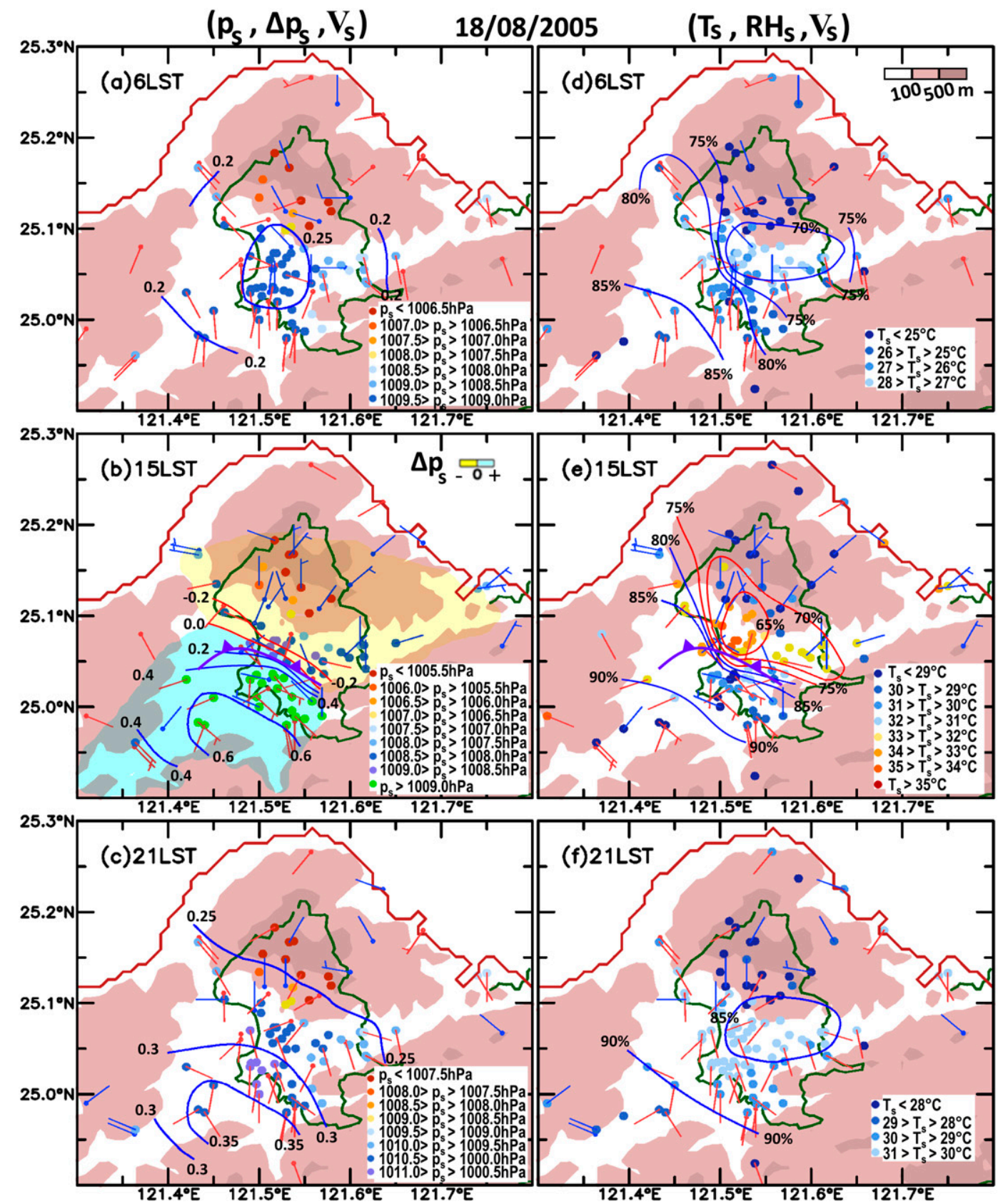

FIG. 9. As in Fig. 6, but for a TS day (18 Aug 2005). The location of the surface front is determined by changes in $\Delta p_{s}, \mathbf{V}_{s}, T_{s}$, and $\mathrm{RH}_{s}$ : a drastic increase of $p_{s}(0.5 \mathrm{hPa}), \mathbf{V}_{s}\left(3 \mathrm{~m} \mathrm{~s}^{-1}\right.$; wind direction changes from sea breezes to land breezes), and $\mathrm{RH}_{s}(15 \%)$ and a drastic decrease in $T_{s}(3 \mathrm{~K})$ in $30 \mathrm{~min}$.

It may not be feasible to present all cases with the approach used in the previous sections. Instead, simple statistics are used to highlight the differences in these salient features between the two groups ( 33 no-TS cases and 32 TS cases), particularly those caused by the TS occurrence in two particular aspects: 1) changes to the basin environment caused by the East Asian synoptic conditions and 2) changes to salient features in diurnal variations of surface meteorological conditions by thunderstorms along the two river valleys.

\section{a. Upper-air synoptic conditions}

The basin environment affected by the synoptic condition change from thunderstorms will be depicted with upper-air soundings for humidity and upper-level circulation. 


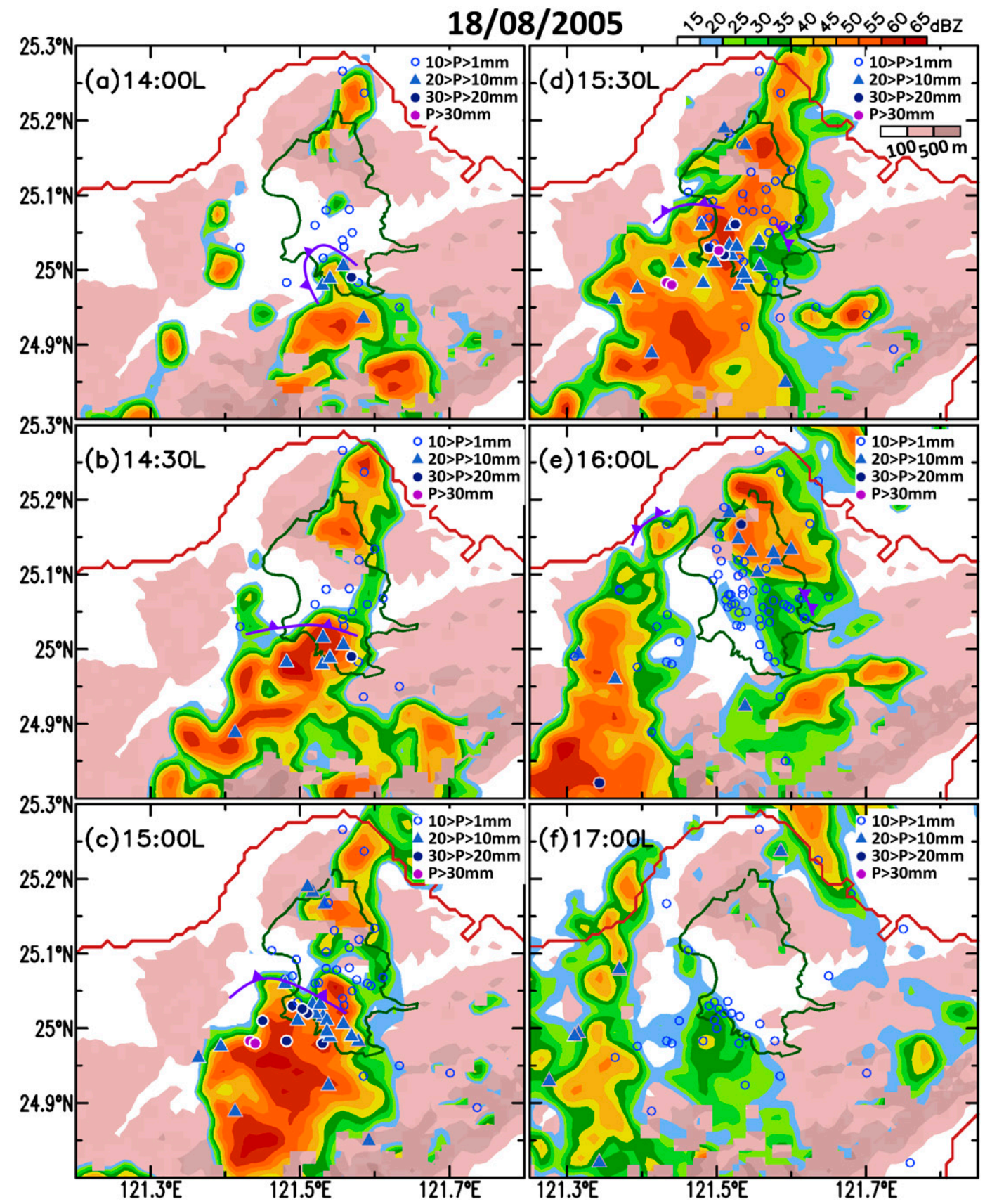

FIG. 10. The radar echo on 18 Aug 2005 (a TS day) at an altitude of $3 \mathrm{~km}$, superimposed with half-hour rainfall accumulation measured by surface stations, is used to depict the TS convection/rainfall over the life cycle of that afternoons' thunderstorms. The rainfall amount is colored by symbols shown in the top-right corner of each panel. The color scale of the radar echo $(1 \mathrm{~km} \times 1 \mathrm{~km}$ resolution $)$ is shown on the top right of the figure. The surface front ahead of the surface mesohigh is determined as in Fig. 9. The selection of the 3-km radar echo is based on the following reasoning: The vertical profile of the radar echo (supplement 9) over its maximum area southwest of the Taipei district shows that the maximum echo is located in the 3-5-km layer; the distribution of the rainfall measurement by surface stations within the Taipei basin and its surrounding areas matches best with the 3-km radar echo. 


\section{1) HUMIDITY CHANGE}

Being linearly and inversely proportionally to $\mathrm{RH}$, $\Delta T_{d}=T-T_{d}$ is often used as an indicator for RH. In Figs. $4 \mathrm{c}$ and $7 \mathrm{c}, \Delta T_{d}(\mathrm{TS})$ values at the surface and above $700 \mathrm{hPa}$ (above the inversion layer) are smaller than for $\Delta T_{d}$ (no-TS). The scatter diagrams at $0000 \mathrm{UTC}$ for $\Delta T_{d}$ at the first level of soundings ( $\sim 60 \mathrm{~m}$; Fig. 11a) and at $500 \mathrm{hPa}$ (Fig. 11b) confirm this $\Delta T_{d}$ contrast is common to the two groups of identified TS and no-TS days. The averaged $\Delta T_{d}$ (TS) and $\Delta T_{d}$ (no-TS) are about 2.0 and $5.5 \mathrm{~K}$, respectively, at the first level of soundings, while the averaged $\Delta T_{d}$ (TS) and $\Delta T_{d}$ (no-TS) are 8.2 and $12.5 \mathrm{~K}$, respectively, at $500 \mathrm{hPa}$. The TS air mass is moister than the no-TS air mass. Using the composite $\left(T, T_{d}\right)$ soundings of 33 no-TS and 32 TS days (Figs. 11c,d), this inference is substantiated by the composite $\delta T_{d}$ $\left[\equiv \Delta T_{d}(\right.$ no-TS $\left.)-\Delta T_{d}(\mathrm{TS})\right]$ vertical profile: $\delta T_{d}>$ 0 over the entire troposphere. These moister conditions facilitate convection/rainfall on TS days.

\section{2) UPPER-LEVEL CIRCULATION CHANGE}

A golden stripe is marked on the $500-850-\mathrm{hPa} \mathbf{~ V}$ soundings at Taipei for both the no-TS and TS groups in Fig. 12. The flows through the lower half of the troposphere across northern Taiwan are primarily easterlysoutheasterly during the no-TS days (Fig. 12a) along the southern part of the ridge north of Taiwan (Fig. 4b). We can infer from $\Delta T_{d}$ (no-TS) that the warm, moist air transport from the northern South China Sea and the Philippine Sea is reduced. Consistent with the southwest monsoon, the lower-tropospheric moist southwesterlies/ westerlies of the TS group (Fig. 12b) facilitate thunderstorm development in the Taipei basin. The distinction between the basic flows for these two groups is more apparent at $700 \mathrm{hPa}$ (Figs. 12c,d).

The flow change between the TS and no-TS groups can be illustrated by the composite TS and no-TS departure flows from the summer-mean flow at $700 \mathrm{hPa}$ for 2004-05. Characterized by the Asian continental thermal low and the North Pacific subtropic anticyclone, this summer-mean circulation (Fig. 13a) is encircled by monsoon westerlies in the south and monsoon southwesterlies in the southeast/east with three monsoon troughs (dashed red lines) and three ridges (solid blue lines) embedded (Krishnamurti 1979). An anomalous anticyclonic shear zone around the Asian continental thermal low appears in the composite 700-hPa TS departure flow (Fig. 13b). Three anomalous anticyclonic cells emerge from this shear zone-the amplification of the three monsoon ridges. The composite $700-\mathrm{hPa}$ noTS departure flow (Fig. 13c) is characterized by an anomalous cyclonic shear zone embedded with three
(a)Surface
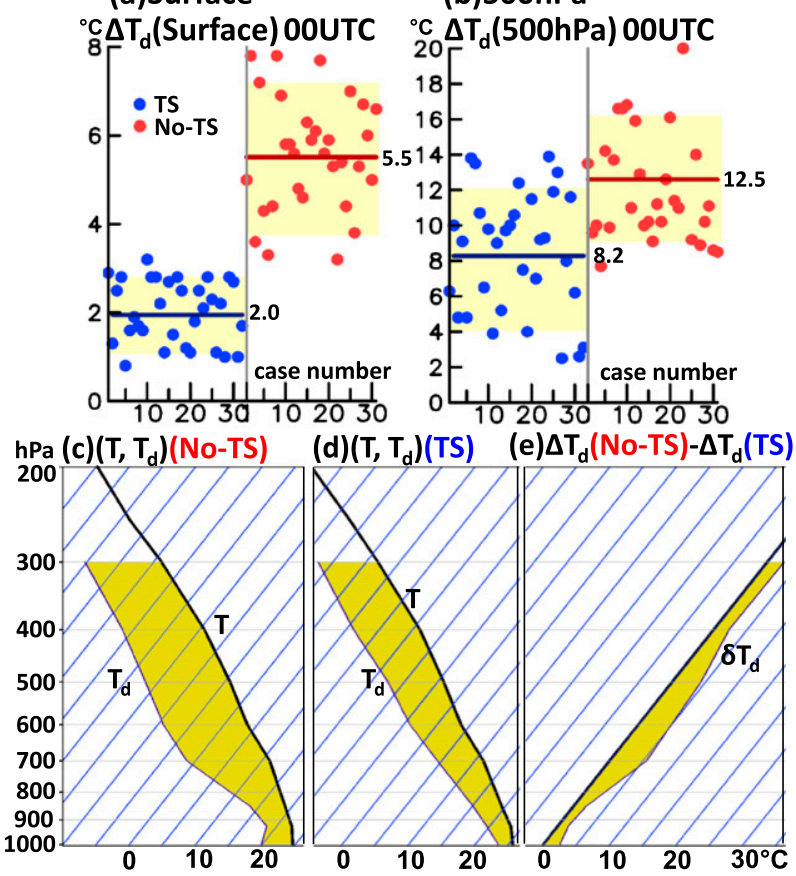

FIG. 11. The 0000 UTC radiosonde measurements of $T$ and $T_{d}$ at Taipei (WMO 46692): scatter diagrams of $\Delta T_{d}\left(=T-T_{d}\right.$ ) on the ordinate vs case number on the abscissa at (a) the first sounding level $(60 \mathrm{~m})$ and (b) $500 \mathrm{hPa}$ for both TS days (blue dots) and no-TS days (red dots) and composite vertical profiles of (c),(d) $T$ and $T_{d}$ for no-TS and TS days, respectively, and (e) $\Delta T_{d}$ (no-TS) $-\Delta T_{d}$ (TS) $=\delta T_{d}$. Standard deviations $\sigma$ of $\Delta T_{d}$ (no-TS) and $\Delta T_{d}$ (TS) are shown by yellow shading in (a) and (b); composites of $\Delta T_{d}$ (no-TS), $\Delta T_{d}$ (TS), and $\delta T_{d}$ are indicated by golden shading in (c)-(e). The two-tailed $t$ test is applied to test whether both groups of $\Delta T_{d}$ (TS) and $\Delta T_{d}$ (no-TS) are statistically different from each other. Results of this $t$ test are the $p$ value of $\Delta T_{d}$ (TS) and $\Delta T_{d}$ (no-TS) at the surface is $0.0026<0.05$ and the $p$ value of $\Delta T_{d}$ (TS) and $\Delta T_{d}$ (no-TS) at $500 \mathrm{hPa}$ is $0.0033<0.05$. For a $p$ value $<0.05$, two sets of $\Delta T_{d}$ s have a $5 \%$ or less chance of belonging to the same group. Therefore, $\Delta T_{d}(\mathrm{TS})$ and $\Delta T_{d}$ (no-TS) are significantly different.

anomalous cyclonic cells-the deepening of the three monsoon troughs.

North of the TS anticyclonic and the no-TS cyclonic shear zone appears a TS anomalous cyclonic cell centered over the Japan Sea and a no-TS anomalous anticyclonic cell centered south of the Yangtze River, respectively. The ridgelines located north of Taiwan during the TS (Fig. 7) and no-TS (Fig. 4) days are reflections of the anomalous TS Taiwan and the no-TS Yangtze River anticyclonic cells, respectively. Thus, the monsoon southwesterly/westerly flow at Taipei is intensified by the former anomalous anticyclonic cell, and is weakened by the easterly/northeasterly anomalies juxtaposed between the latter anticyclonic cell and the Philippine Sea cyclonic cell. Apparently, the direction and magnitude change for the lower-tropospheric 
(a) Taipei soundings of V(00UTC; 08LST): No-TS days
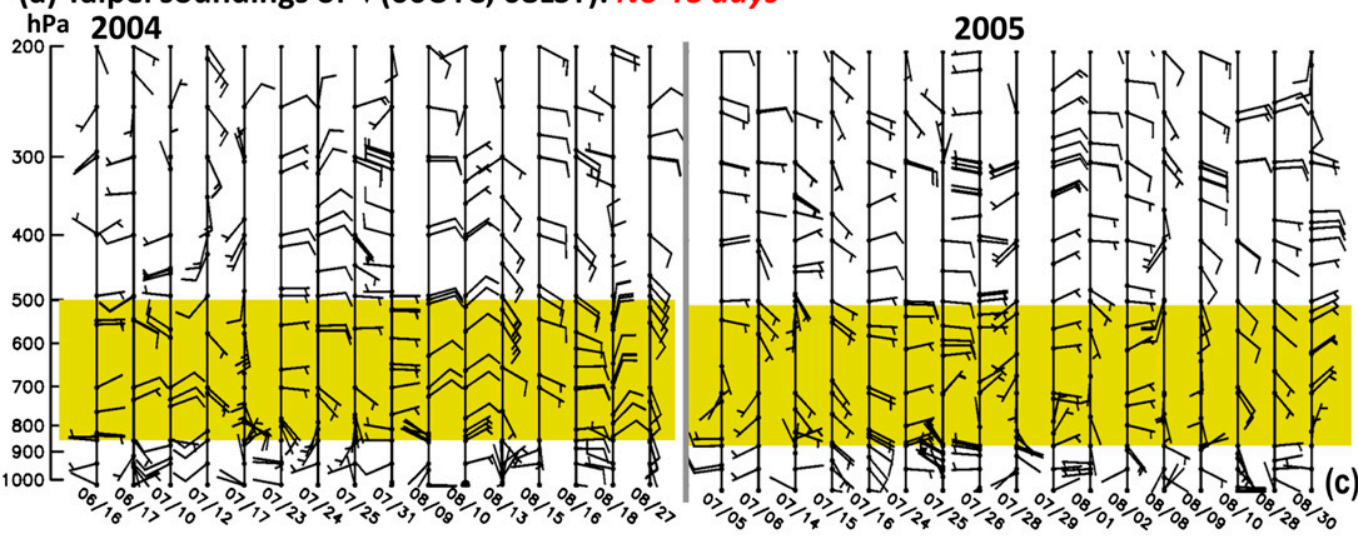

(c) No-TS (d)
days
V(700hPa)

(d)TS days

(b) Taipei soundings of V(00UTC; 08LST): TS days
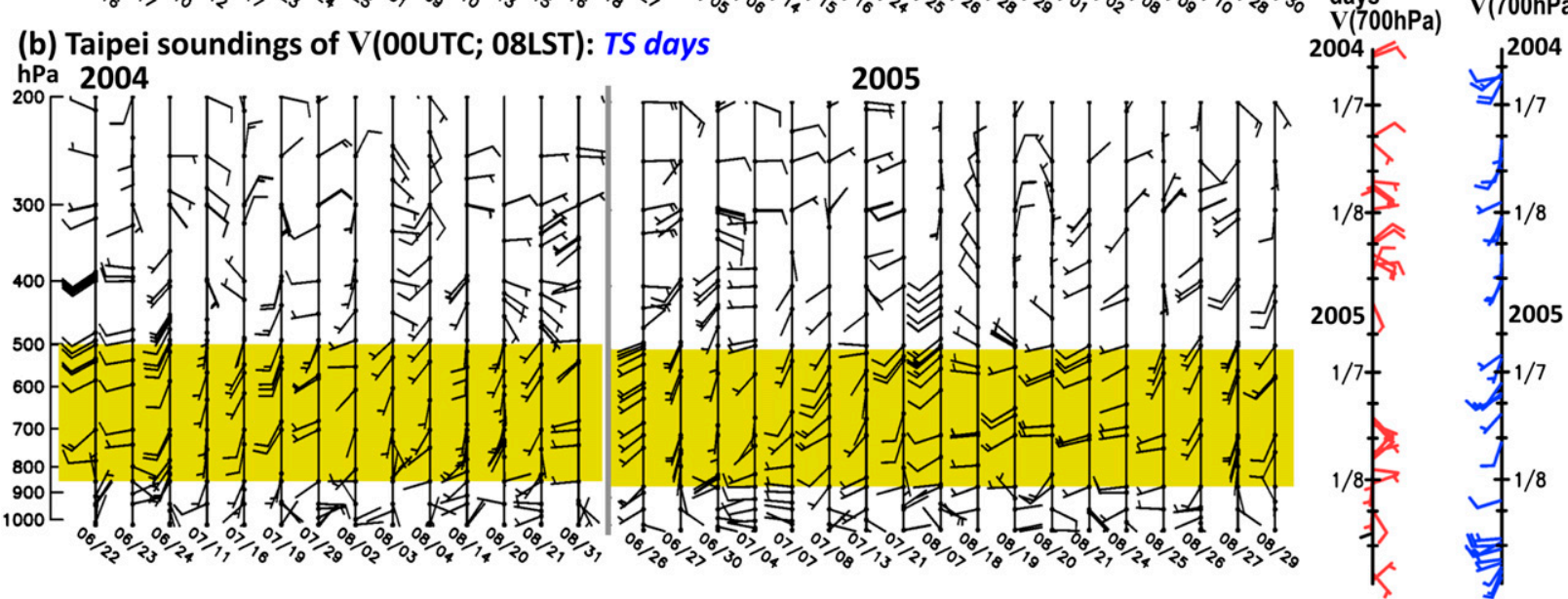

FIG. 12. The Taipei $\mathbf{V}$ soundings at 0000 UTC for (a) 33 no-TS days and (b) 32 TS days over the summers of 2004 and 2005 . The lowertropospheric monsoon flows at Taipei are shown by the $\mathbf{V}$ soundings over the 850-500-hPa layer marked with a golden stripe. To show the directional consistency of these monsoon flows, the $\mathbf{V}(700 \mathrm{hPa}$ ) wind vectors for all 33 no-TS days and 32 TS days are presented in (c) and (d), respectively.

environmental flow at Taipei are indicators of the Asian monsoon circulation change favorable (unfavorable) for developing the TS (no TS) events in the Taipei basin.

\section{b. Basin meteorological condition changes by thunderstorms}

Following sections 3 and 4, the basin meteorological condition changes by thunderstorms are highlighted with the following salient features.

\section{1) SuRfACE PRESSURE}

The timings and magnitudes for $p_{s}$ minima/maxima over a day at Taipei (station 5) for all identified cases of the no-TS and TS groups are shown in Fig. 14 (summarized in Table 4). Both groups exhibit a clear semidiurnal variation. Occurrences for minima and maxima in the $p_{s}(\mathrm{TS})$ diurnal variation are about 1$1.5 \mathrm{~h}$ behind those in the $p_{s}$ (no-TS) cases, except the major daytime $p_{s}(\mathrm{TS})$ minimum is about $1.5 \mathrm{~h}$ ahead of $p_{s}$ (no-TS) and is caused by the afternoon TS rainfall followed by the mesohigh formation. The averaged results summarized in Table 4 are consistent with those for individual no-TS (Fig. 5) and TS (Fig. 8) cases shown in Table 2. The semidiurnal $p_{s}(\mathrm{TS})$ and $p_{s}$ (no-TS) components should be comparable in amplitude and coincident in time. Differences (magnitude and timing) between $p_{s}\left(\right.$ no-TS) and $p_{s}(\mathrm{TS})$ maxima/minima are attributed to the $p_{s}$ (TS) diurnal component (supplement 10 of the supplemental material).

\section{2) Surface temperature}

As may be inferred from $\Delta T_{d}(\mathrm{TS})<T_{d}(\mathrm{TS})$ at the surface (Fig. 11), the 32 TS days should be moister than the 33 no-TS days. The surface is cooled more by the longwave radiative cooling during the clear-dry night than the moist, cloudy night (e.g., Hess 1979; Liou 2002). At the two river exit stations (Tanshui and Keelung) and Taipei, the early morning $T_{s}$ (TS) minima occur about $1 \mathrm{~h}$ behind and $1 \mathrm{~K}$ higher than the $T_{s}$ (no-TS) minima (left of each panel in Fig. 15) before sunrise. After sunrise, the shortwave radiative heating warms $T_{s}(\mathrm{TS})$ to reach its maximum at $1200 \mathrm{LST}, 2 \mathrm{~h}$ before $T_{s}$ (no-TS) (middle 


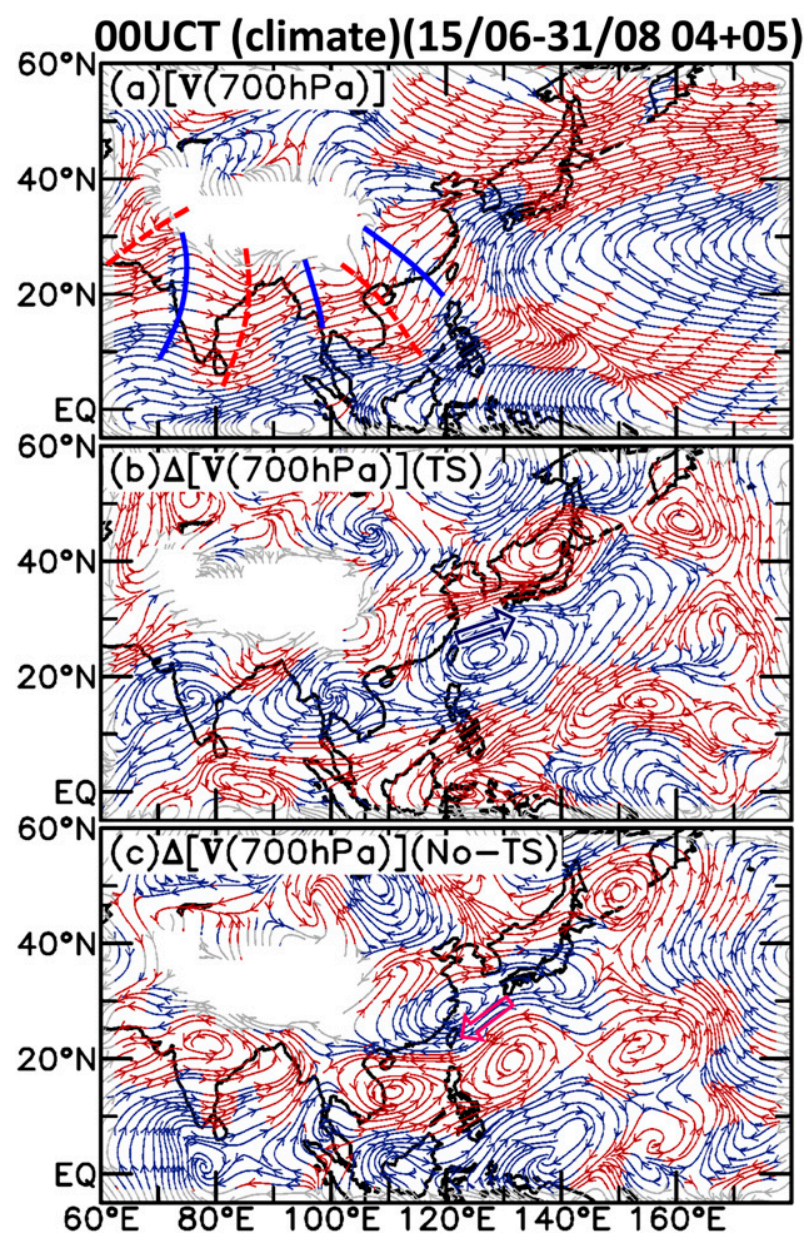

FIG. 13. The monsoon circulation in the lower troposphere and the composite departure flows for the TS and no-TS days over the period for 15 Jun-31 Aug (revival phase of the East Asian monsoon) for 2004 and 2005 are depicted with 700-hPa streamline charts: (a) the time-mean flow, (b) the composite TS departures flows, and (c) the composite no-TS departure flow. The cyclonic and anticyclonic flows are portrayed by red and blue streamlines, respectively. The trough and ridge lines for the monsoon flow over southern/Southeast Asia in (a) are indicated by thick solid blue lines and thick dashed red lines, respectively. The southwest departure flows from Taiwan in (b) and the northeast departure flows toward Taiwan in (c) are marked by open blue and red arrows, respectively.

of each panel in Fig. 15). Although $T_{s}$ (no-TS) gradually cools, the basin environment of the TS days enables $T_{s}(\mathrm{TS})$ to fall between 1200 and $1300 \mathrm{LST}$ and reach its minimum immediately after the onset of thunderstorm rainfall (right of each panel in Fig. 15).

\section{3) Surface RELATIVE HuMidity}

Checking through the $\mathrm{RH}_{s}$ time series for all $32 \mathrm{TS}$ days for the 12 stations along the two river valleys (thin blue lines), a moderate overshooting of RH(TS) ( $~ 5 \%$ increase at Taipei station; see Fig. 16) appears during

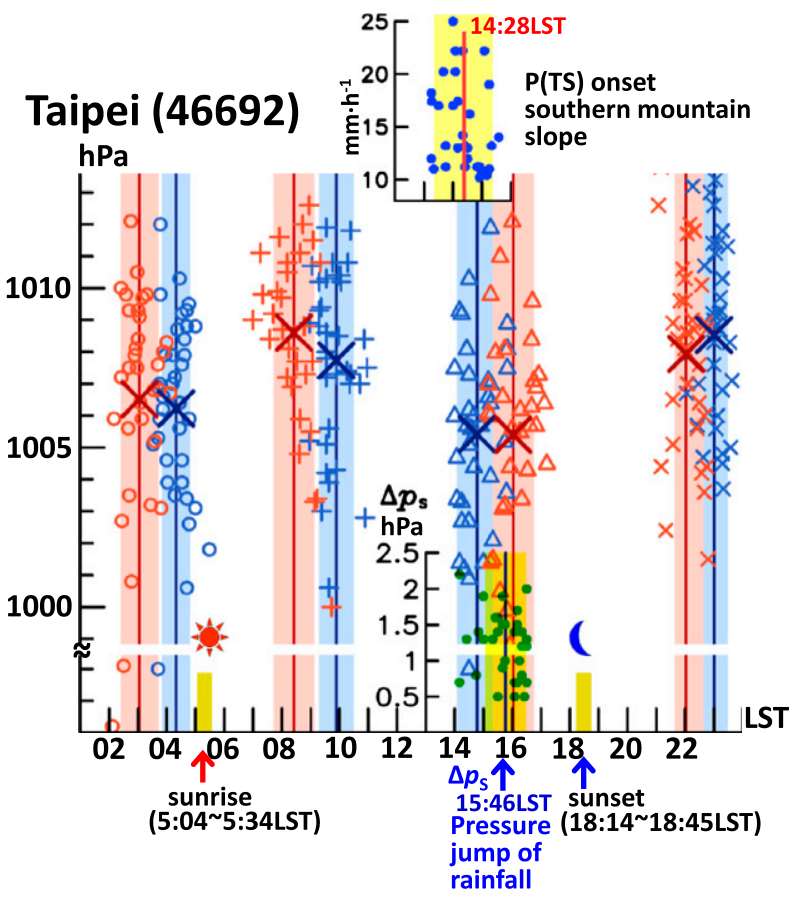

FIG. 14. The $p_{s}$ minima/maxima revealed by its diurnal variations over a day at station 5 (Taipei) for all 33 no-TS days and 32 TS days identified are projected onto a plane with their timings (abscissa) and magnitudes (ordinate). The early morning (afternoon) $p_{s}$ (noTS) minima are marked with open red circles (triangles), while the morning (late night) $p_{s}$ (no-TS) maxima are denoted by red plus (times) signs. The $p_{s}(\mathrm{TS})$ minima/maxima corresponding to the $p_{s}$ (no-TS) counterparts are marked in blue. The average timings of the $p_{s}\left(\right.$ no-TS) $\left[p_{s}(\mathrm{TS})\right]$ minima/maxima are indicated by red (blue) lines, while the average magnitudes of $p_{s}\left(\right.$ no-TS) $\left[p_{s}(\mathrm{TS})\right]$ are marked by large red (blue) times signs with additionally $\pm 1 \sigma$ [pink (light blue)] shading. The first time for the TS rainfall amount $P$ (TS) $\geq 10 \mathrm{~mm} \mathrm{~h}^{-1}$ near/over mountain slopes south of the Taipei basin $P_{s}$ (TS) (blue dots) for all 32 TS days, with the averaged timing for $P(\mathrm{TS}) \geq 10 \mathrm{~mm} \mathrm{~h}^{-1}$ indicated by the vertical red line, is shown in the top center of the figure. The maximum $p_{s}$ (TS) jumps $\Delta p_{S}$ s (green dots) after the TS rainfall for all 32 TS days, with the averaged timing indicated by the short black vertical line, are shown in the bottom center of the figure. As in Fig. 11, results of this $t$ test are the $p$ value for occurrence times between the first minimum of $p_{s}(\mathrm{TS})$ and $p_{s}($ no-TS $)=0.0032<0.05$, the $p$ value for occurrence times between the first maximum of $p_{s}(\mathrm{TS})$ and $p_{s}($ no-TS $)=$ $0.0019<0.05$, the $p$ value for occurrence times between the second minimum of $p_{s}$ (TS) and $p_{s}($ no-TS $)=0.0028<0.05$, and the $p$ value for occurrence times between the second maximum of $p_{s}(\mathrm{TS})$ and $p_{s}($ no-TS $)=0.0037<0.05$. On the basis of these $p$ values, the occurrence times between two sets of minimum or maximum $p_{s}(\mathrm{TS})$ and $p_{s}$ (no-TS) have less than a $5 \%$ chance of belonging to the same group. Therefore, occurrence times between minimum or maximum $p_{s}(\mathrm{TS})$ and $p_{s}($ no-TS) are significantly different.

$86 \%$ of these TS days (supplement 11 of the supplemental material), when $T_{s}$ (TS) drops to its early morning minimum before sunrise. It appears that $\mathrm{RH}_{s}(\mathrm{TS})$ is more sensitive to $T_{s}(\mathrm{TS})$, when $\Delta T_{d}(\mathrm{TS})$ is small (air mass is moist). At some stations $\mathrm{RH}_{s}$ (no-TS) may 
TABLE 4. Averaged timing (LST) of $32 p_{s}$ (TS) and $33 p_{s}$ (no-TS) maxima and minima at station 5 (Taipei).

\begin{tabular}{lcccc}
\hline \hline & $\begin{array}{c}\text { Early } \\
\text { morning } \\
\min \end{array}$ & $\begin{array}{c}\text { Daytime } \\
\max \end{array}$ & $\begin{array}{c}\text { Major } \\
\text { daytime } \\
\min \end{array}$ & $\begin{array}{c}\text { Late } \\
\text { night } \\
\max \end{array}$ \\
\hline$p_{s}$ (no-TS) & 0300 & 0820 & 1600 & 2200 \\
$p_{s}$ (TS) & 0418 & 0955 & 1450 & 2300 \\
Timing difference & $1 \mathrm{~h}, 18 \mathrm{~min}$ & Sunrise & \multicolumn{2}{c}{ Sunset } \\
\end{tabular}

exhibit such an $\mathrm{RH}_{s}$ (no-TS) overshooting, when $T_{s}$ (noTS) reaches its early morning minimum. This overshooting occurs for about $8 \%$ of the 33 no-TS days (supplement 11). The moderate overshooting of $\mathrm{RH}_{s}(\mathrm{TS})$ at about 0500 LST is a ubiquitous feature on almost all TS days. Another significant $\mathrm{RH}_{s}$ diurnal variation feature involves a sudden $\mathrm{RH}_{s}($ no-TS) jump right at sunset (thick green line in Fig. 16), but $\mathrm{RH}_{s}(\mathrm{TS})$ undergoes a dramatic increase $(\sim 30+\%)$ from its daytime minimum [when $T_{s}$ (TS) is maximum at $1200 \mathrm{LST}$ ], as soon as thunderstorm rain falls at about 1500 LST (red line in Fig. 16).

\section{4) Alternation OF THE LAND-SEA BREEZES By THUNDERSTORMS}

Timings for the SB onset and cessation at the exit and terminal stations of the two river valleys are shown in Fig. 17 and tabulated in Table 5: the mean SB(no-TS) onset time at the two river exit stations (stations 1 and 7) is about 1000 LST, and about 1200 LST at the slope stations (stations 7 and 11). The mean SB (no-TS) onset times vary within the range observed in Fig. 5. The sunset during summer (June-August, JJA) in Taiwan occurs during 1814-1845 LST. The SB(no-TS) cessation at all stations along the two river valleys occurs within a half-hour window before-after sunset. The LB onset regulated by the nighttime radiation cooling, as pointed out in section $3 \mathrm{a}$, is confirmed here. The SB(no-TS) life span is about $7 \mathrm{~h}$ near mountain slopes and $9 \mathrm{~h}$ at the river exit stations. The $\mathrm{SB}(\mathrm{TS})$ onset time is about 1000 LST at the two river exit stations, but about 1030 LST near the mountain slopes. Different from the SB(no-TS) cessation time, the SB(TS) ceases as soon as thunderstorm rain falls close to 1500 LST near the mountain slopes and 1630 LST at the river exit stations. Consequently, the $\mathrm{SB}$ (TS) life cycle, shorter than the SB(noTS) life cycle, is about $4.5 \mathrm{~h}$ closer to the mountain slopes and slightly shorter than $7 \mathrm{~h}$ at the river exits. In view of the time difference for the SB life cycle and the difference for the SB cessation mechanism between the no-TS and TS groups, the afternoon thunderstorm activity exerts

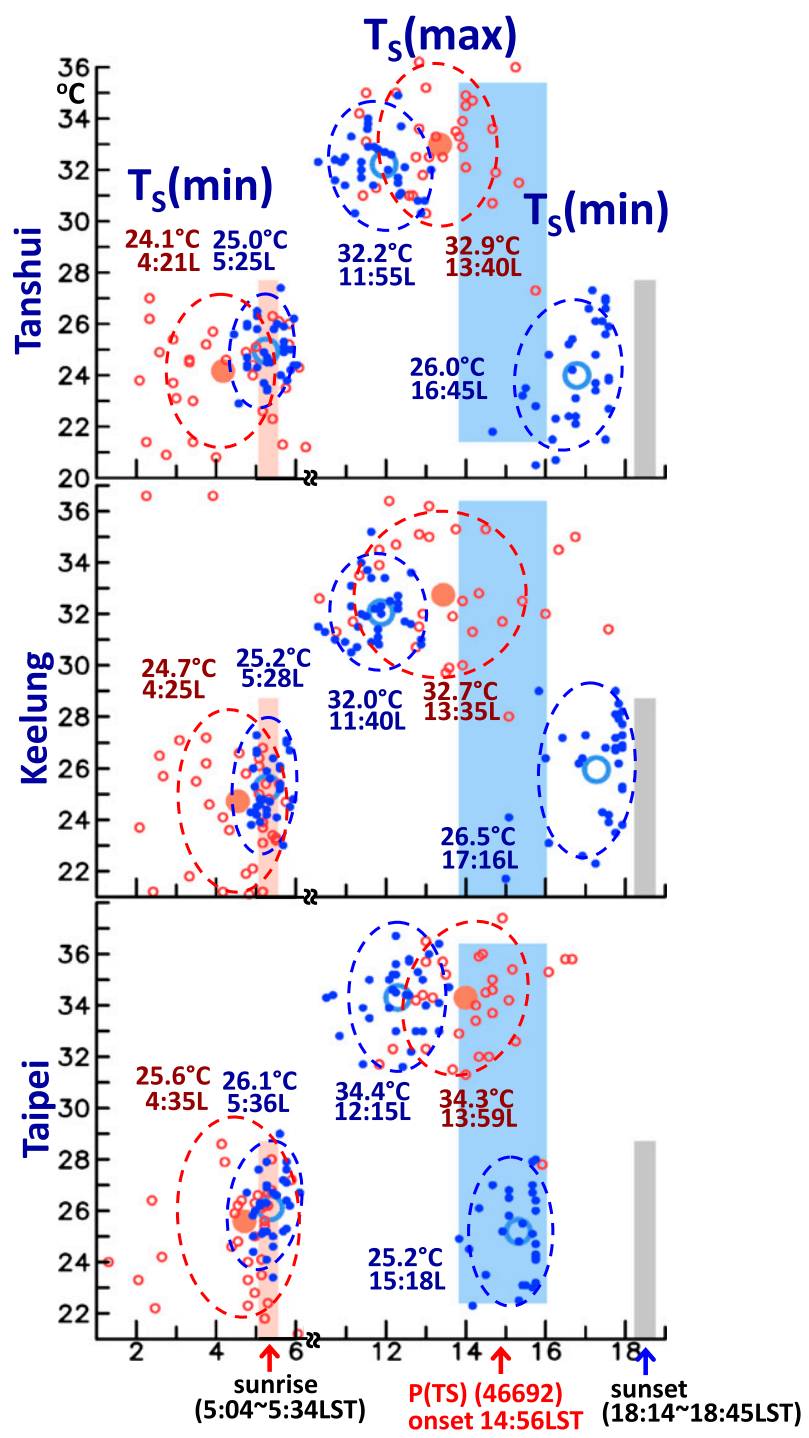

FIG. 15. Scatter diagrams for timing (abscissa) vs magnitudes (ordinates) for $T_{s}$ minima and maxima resulting from $T_{s}$ diurnal variations over a day at three stations in the Taipei basin-Tanshui (WMO 46690), Taipei (WMO 46692), and Keelung (WMO 46694) - for 33 no-TS days (open red circle) and 32 TS days (dark blue dots) during 15 Jun-31 Aug 2004 and 2005. Average timings and magnitudes of $T_{s}$ (no-TS) and $T_{s}$ (TS) minima/maxima are marked by large filled dots and large open circles, respectively, encircled by $1 \sigma$ of the corresponding minima/maxima.

a significant impact not only on the Taipei basin-open sea airmass ventilation mechanism, but also on the diurnal variations of meteorological conditions and the basin environment.

\section{5) LIFE CYCLE OF AFTERNOON THUNDERSTORMS}

Afternoon thunderstorms are an essential part of the land-sea-breeze life cycle during the TS days in the 
RHs(TS), composite[RHs(TS)] Taipei(46692)

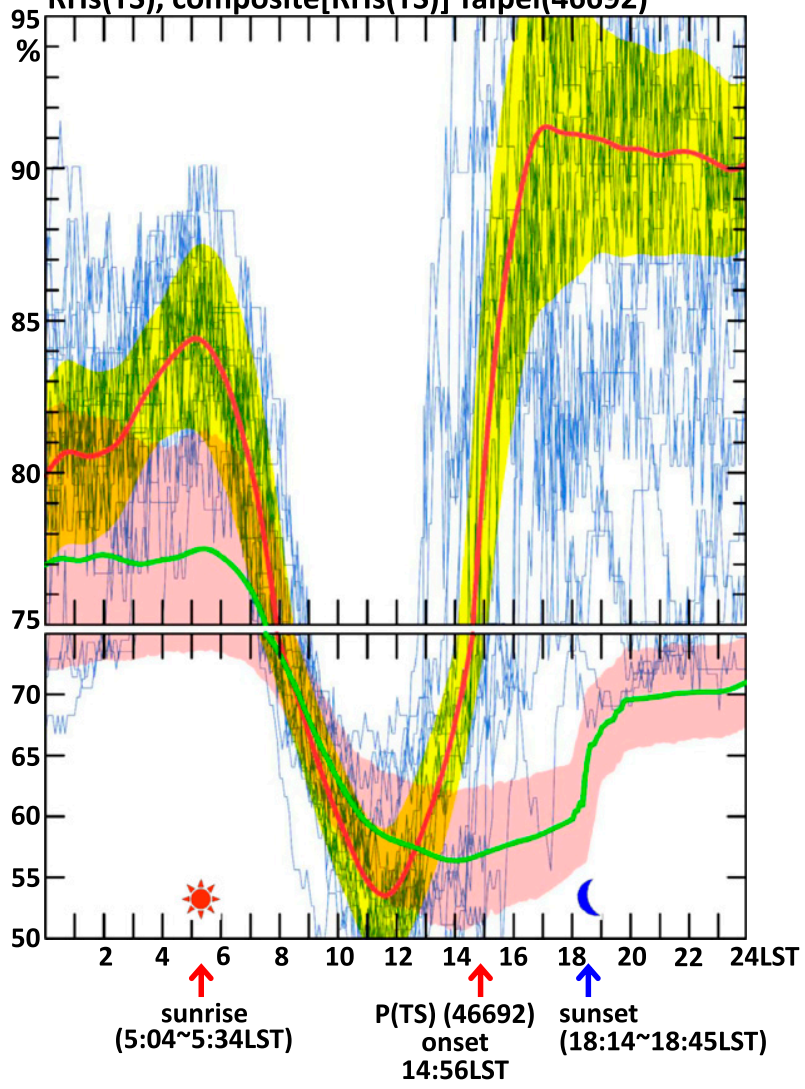

FIG. 16. Composite $\mathrm{RH}_{s}$ (TS) time series at Taipei (WMO 46692) for $32 \mathrm{TS}$ days (thick red line) superimposed with $1 \sigma$ (yellow shading). The real-time $\mathrm{RH}_{s}(\mathrm{TS})$ time series for each individual TS day is portrayed by the thin blue line. The composite $\mathrm{RH}_{s}$ (no TS) time series for the 33 no-TS days (thick green line) superimposed with $1 \sigma$ (pink shading) is also added for reference. The sunrise and sunset times in the middle of the monsoon revival phase are marked at the bottom with an onset time for when the TS rainfall reaches $10 \mathrm{~mm} \mathrm{~h}^{-1}$ for the first time. The composite procedure consists of the following three steps: 1) select the $\mathrm{RH}_{s}$ surge case (with a moderate overshooting in the early morning) and compute the averaged time of the early morning $\mathrm{RH}_{s}$ maximum, 2) align times of maxima $\mathrm{RH}_{s}$ for all cases in the morning to the average time of the $\mathrm{RH}_{s}$ overshooting, and 3) average the aligned time series of $\mathrm{RH}_{s}$.

Taipei basin. Thus, the question arises of whether the afternoon thunderstorm life cycle presented in Fig. 10 is anticipated to be common to all 32 identified TS days. Because radar echoes are not available during the entire field experiment, station rainfall measurements during the experiment are analyzed to answer this question. Not every afternoon thunderstorm life cycle is $2 \mathrm{~h}$, but about $60 \%$ of them exhibit such a life cycle, as shown in Fig. 10. The composite procedure is applied to the rainfall distributions for the three phases of these afternoon thunderstorms' life cycles. As depicted with radar echoes in Fig. 10, the initial phase is characterized
TABLE 5. Onset and cessation time and life span of the sea breezes at the valley exit stations (lightface font) and stations close to mountain slopes (boldface font) along the Tanshui and Keelung River valleys.

\begin{tabular}{|c|c|c|c|c|c|}
\hline $\begin{array}{l}\text { River } \\
\text { valley }\end{array}$ & Type & Station & $\begin{array}{l}\text { Onset } \\
\text { time } \\
(\mathrm{LST})\end{array}$ & $\begin{array}{c}\text { Cessation } \\
\text { time } \\
(\mathrm{LST})\end{array}$ & Duration \\
\hline \multirow[t]{4}{*}{ Tanshui } & \multirow[t]{2}{*}{ No TS } & Tanshui & 0958 & 1855 & $8 \mathrm{~h}, 57 \mathrm{~min}$ \\
\hline & & Jin-mei & 1204 & 1818 & $6 \mathrm{~h}, 14 \mathrm{~min}$ \\
\hline & \multirow[t]{2}{*}{ TS } & Tanshui & 0956 & 1634 & $6 \mathrm{~h}, 38 \mathrm{~min}$ \\
\hline & & Jin-mei & 1026 & 1442 & $4 \mathrm{~h}, 16 \mathrm{~min}$ \\
\hline \multirow[t]{4}{*}{ Keelung } & \multirow[t]{2}{*}{ No TS } & Keelung & 0950 & 1852 & $9 \mathrm{~h}, 02 \mathrm{~min}$ \\
\hline & & Panchao & 1205 & 1815 & $6 \mathrm{~h}, 10 \mathrm{~min}$ \\
\hline & \multirow[t]{2}{*}{ TS } & Keelung & 0956 & 1648 & $6 \mathrm{~h}, 52 \mathrm{~min}$ \\
\hline & & Panchao & 1032 & 1450 & $4 \mathrm{~h}, 18 \mathrm{~min}$ \\
\hline
\end{tabular}

by TS rainfall over mountain slopes south of the basin (Fig. 18a). The maximum TS rainfall appears in the central basin during the mature phase (Fig. 18b). The TS rainfall declines in the central basin, but diverges toward the surrounding mountains and eventually disappears in the dissipation phase (Fig. 18c).

\section{Concluding remarks}

The Taipei Basin Experiment was conducted during the summers (June-August) of 2004 and 2005 by enhancing the already existing mesonetwork to address two major issues: 1) how the land-sea breeze behaves inside the Taipei basin and 2) how afternoon thunderstorms in this basin change the behavior of the basin land-sea breezes and the basin's meteorological conditions. For this experiment, $32(\sim 20 \%)$ and $33(\sim 21 \%)$ of 156 days are identified as afternoon thunderstorm and no-thunderstorm days, respectively. Along with the data measured during this experiment, the two aforementioned scientific issues are investigated by a comparison study of the synoptic environment around Taiwan and the diurnal variation of the meteorological conditions in the Taipei basin between no-TS and TS days.

The land-sea-breeze life cycle in the Taipei basin is depicted by the sea-breeze onset at about 1000 LST near the coast and at about 1200 LST over the mountain slopes south of the Taipei basin, as well as the onset (cessation) of the land (sea) breeze immediately after sunset over the entire basin. The sea-breeze onset needs more time to develop the land-sea thermal contrast by the daytime shortwave radiative heating, while the mountain longwave radiative cooling enables the landbreeze onset to occur relatively uniformly over the basin. Apparently, the radiative heating-cooling pattern of the mountains around this basin regulates the life cycle of the land-sea breeze within the basin in a more stringent manner. 
(a) Tanshui River Valley

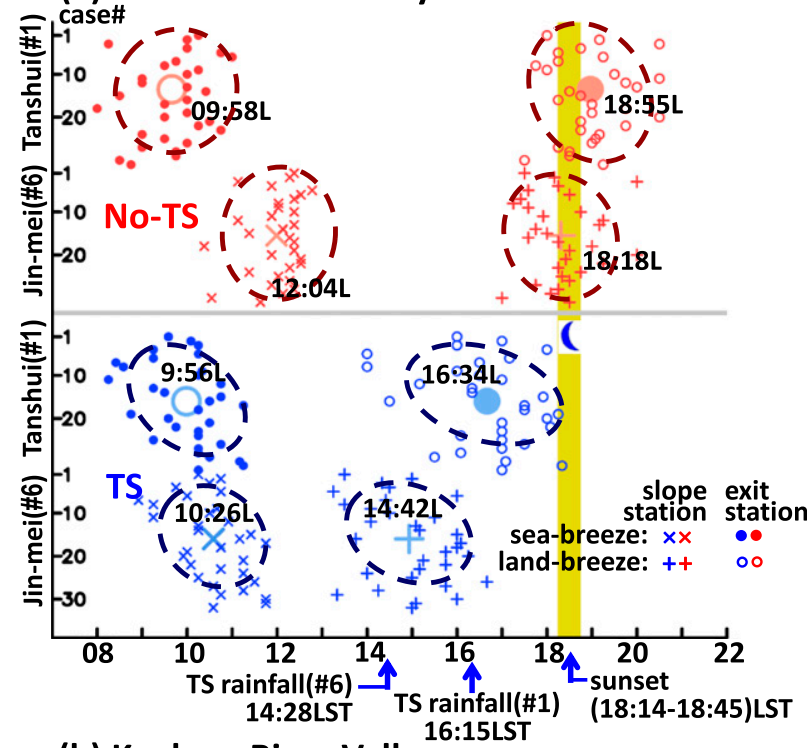

(b) Keelung River Valley

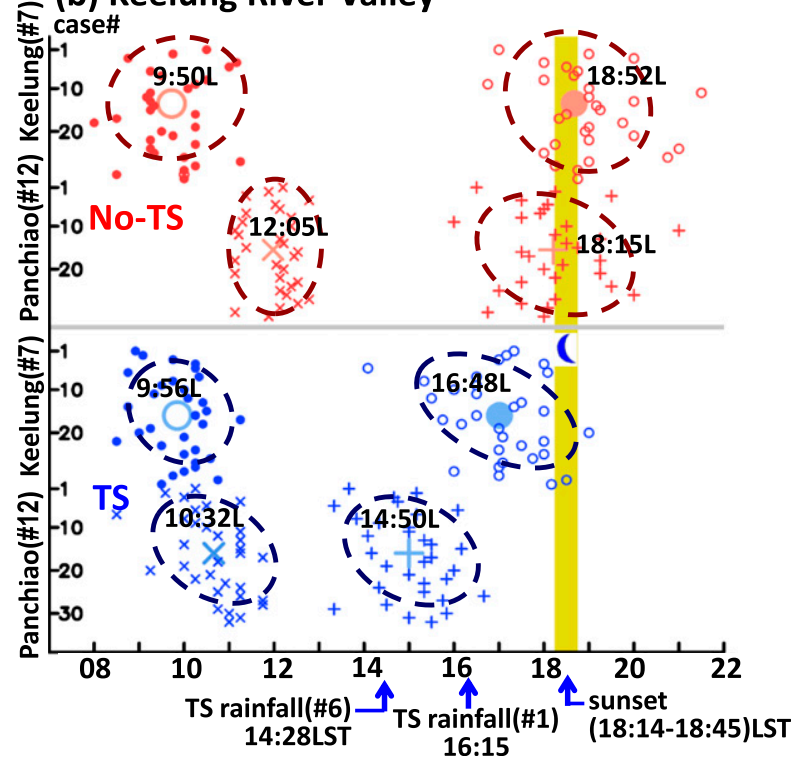

FIG. 17. The SB onset and cessation times at valley exit and mountain-slope stations for the (a) Tanshui and (b) Keelung river valleys for the 33 no-TS (red) and 32 TS (blue) days during the summers of 2004 and 2005. These stations are Tanshui (exit station 1; WMO 46690) and Jin-mei (slope station 6; EPA 004) along the Tanshui River valley and Keelung (exit station 7; WMO 46694) and Penchiao (slope station 11; WMO 46688) along the Keelung River valley. Symbols used to indicate the onset and cessation times at exit and slope stations are explained at the bottom of (a), and sunset is marked by a golden stripe. The averaged onset (cessation) time for the exit stations is marked by a large open circle (filled dot), while that for slope stations is denoted by a large times (plus) sign. The $1 \sigma$ around the mean values are encircled by dashed oblongs.

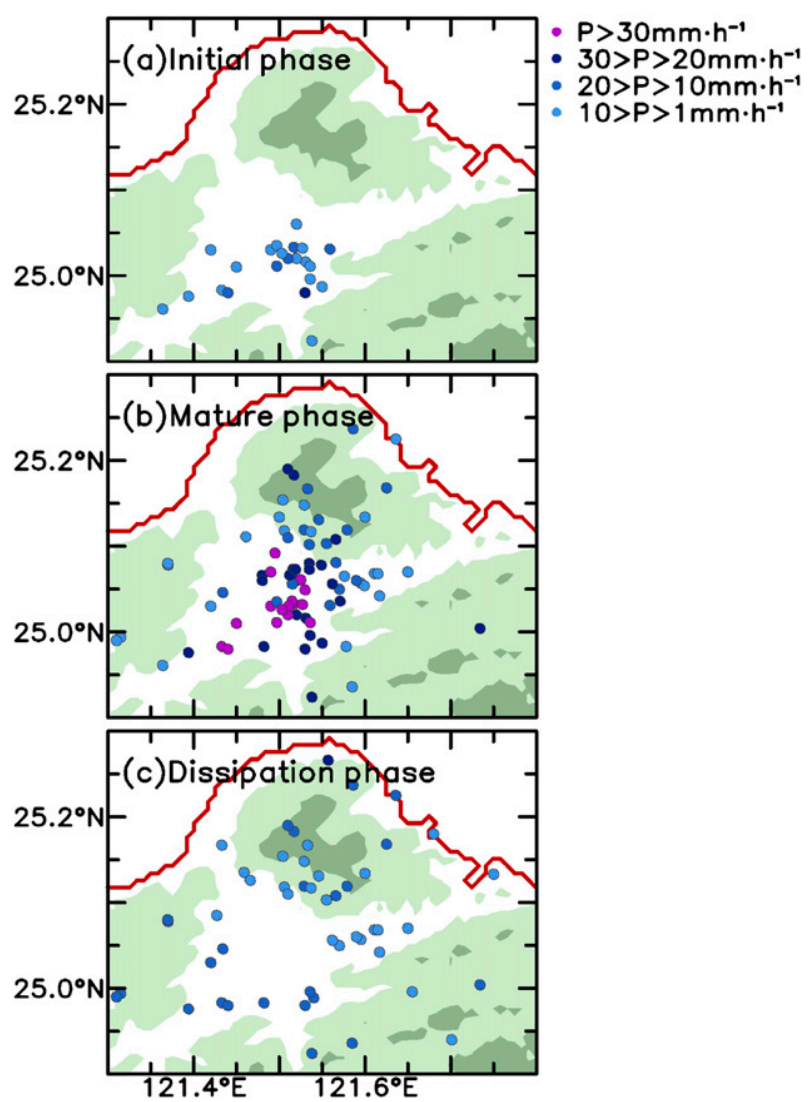

FIG. 18. Composite life cycle of afternoon thunderstorms in the Taipei basin depicted with station rainfall measurements over the TBEX domain (Fig. 2). The afternoon thunderstorm life cycle is depicted with 30-min rainfall accumulations. As long as the life cycle of any TBEX afternoon thunderstorm follows the behavior shown in Fig. 10 (regardless of the duration of its life cycle), the thunderstorm is selected to construct a composite three-phase life cycle. The composite rainfall pattern for each phase is the average rainfall for this phase of all selected thunderstorm cases: (a) initial, (b) mature, and (c) composite phases. The magnitude of TS rainfall at each station is represented by the color scale to the right of (a).

As seen from the contrast for $\Delta T_{d}$ at the surface and the ambient flows in the $850-500-\mathrm{hPa}$ layers between noTS and TS days, the warm, moist monsoon southwesterly/ southerly flow toward northern Taiwan is intensified (weakened) during the latter (former) group of days to facilitate (hinder) afternoon thunderstorm activity in the Taipei basin. When the afternoon thunderstorm rain falls around $1400 \mathrm{LST}, T_{s}$, and $p_{s}$ dramatically drop and a surface mesohigh forms over the mountain slopes south of the basin. The sea breeze is switched to a land breeze by this mesohigh. At the same time, $\mathrm{RH}_{s}$ rapidly increases over $30 \%$ within a couple of hours. The SB lifetime is significantly reduced from $6-9 \mathrm{~h}$ for $\mathrm{SB}$ (no-TS) to $4.5-7 \mathrm{~h}$ for $\mathrm{SB}$ (TS). The ventilation mechanism of the air masses inside the basin is drastically 
changed. The intrusion of the open-sea fresh air by the sea breeze into the basin during the no-TS day can be sustained for about $8 \mathrm{~h}$. In contrast, the polluted air can be swept out of the basin by the land breeze after the thunderstorm rainfall in late evening to the next morning, which takes about $18-20 \mathrm{~h}$.

The life cycle of afternoon thunderstorms in the Taipei basin can be portrayed in three phases with the convective system revealed from radar echoes. In the initial phase the moist, unstable, southwesterly monsoon flow is transported by the sea breeze into the basin. The interaction of this sea breeze with the Taipei UHI and the orography south of the Taipei basin triggers the onset of the TS convection/rainfall at about 1400 LST over the mountain slopes south of this basin, along with the formation of a cold front. In the mature phase, the TS convection/rainfall spreads farther northward to cover the basin and the mountains south and north of the basin. A mesohigh forms south of the cold front, which couples with a wind surge and moves northward to the northern basin. During the dissipation phase, the downdraft over the mesohigh suppresses the TS convection-rainfall in the central basin and diverges it outward. The interaction of this outflow with the surrounding mountains causes the TS convection/rainfall to occur over these mountains, but the weakening of this interaction leads to the demise of the TS activity at 1700 LST.

The analysis of this experiment provides a relatively comprehensive and new perspective of the land-seabreeze life cycle and the impact of afternoon thunderstorm activity in the Taipei basin, but the scope of some aspects of this research are still limited and require further investigative efforts:

1) Because of the heavy air traffic over this basin, upper-air soundings can only be performed twice daily and upper-level measurements with an unmanned aircraft are not permissible. Radar wind data can be generated (Miller and Anderson 1991), but are limited to periods when clear echoes are available. The three-dimensional structure of the convective system associated with the basin's afternoon thunderstorm should be animated over its life cycle.

2) Inferred from the onset location of the TS convection/ rainfall over mountain slopes south of the basin, the UHI effect and the SB-orography interaction are basic mechanisms used to induce the genesis of convection in the Taipei basin. This inference should be substantiated by a numerical study.

3) The TS rainfall shortens the SB life cycle, modifies the diurnal variation of the basin's meteorological conditions, and alters the Taipei basin-open sea airmass ventilation process. Forecasts for the occurrence of afternoon thunderstorms and the timing of TS rainfall in this basin are a great challenge in the operational model.

4) Diurnal variations of $T_{s}(\mathrm{TS})$ or $\mathrm{RH}_{s}(\mathrm{TS})$ and $T_{s}$ (noTS) or $\mathrm{RH}_{s}($ no-TS) over the basin exhibit pronounced differences. Because variations for $\mathrm{RH}_{s}$ may not be inversely related to $T_{s}$ (Lawrence 2005), a detailed analysis of the surface energy budget (Shepherd 2005) would enhance our understanding of these differences.

5) Rainfall is primarily maintained by the convergence of the water vapor flux. The downscale maintenance of the TS rainfall in the Taipei basin requires further research. Results of this effort can provide some hydrological insights into improving the operational forecast for the afternoon TS rainfall in this basin.

Acknowledgments. This study was partially sponsored by the Cheney Research Fund and NSF Grant ATM-0836220. MCY's effort was supported by NSC102-2111-M-008-024. EST acknowledges partial support from the Iowa Economic Development Authority (formerly Iowa Office of Energy Independence) under Award 09-IPF-14. Comments and suggestions offered by two reviewers and Dr. Joseph Charney (editor) were very helpful during the revision of this paper.

\section{REFERENCES}

Atkins, N. T., and R. M. Wakimoto, 1997: Influence of the synopticscale flow on sea breezes observed during CaPE. Mon. Wea. Rev., 125, 2112-2130, doi:10.1175/1520-0493(1997)125<2112: IOTSSF $>2.0 . \mathrm{CO} ; 2$.

Banta, R. M., 1995: Sea breezes shallow and deep on the California coast. Mon. Wea. Rev., 123, 3614-3622, doi:10.1175/ 1520-0493(1995)123<3614:SBSADO > 2.0.CO;2.

Bastin, S., and P. Drobinski, 2006: Sea-breeze-induced mass transport over complex terrain in south-eastern France: A case-study. Quart. J. Roy. Meteor. Soc., 132, 405-423, doi:10.1256/qj.04.111.

Carbone, R. E., W. A. Cooper, and W.-C. Lee, 1995: Forcing of flow reversal along the windward slopes of Hawaii. Mon. Wea. Rev., 123, 3466-3480, doi:10.1175/1520-0493(1995)123<3466: FOFRAT $>2.0 . \mathrm{CO} ; 2$.

Case, J. L., M. M. Wheeler, J. Manobianco, J. W. Weems, and W. P. Roeder, 2005: A 7-yr climatological study of land breezes over the Florida Spaceport. J. Appl. Meteor., 44, 340-356, doi:10.1175/JAM-2202.1.

Chen, T.-C., M.-C. Yen, and R. Arritt, 1998: Detection of semidiurnal wind oscillation with a radar wind profile. Bull. Amer. Meteor. Soc., 79, 1921-1924.

_- — - J.-C. Hsieh, and R. W. Arritt, 1999: Preliminary results of the rainfall measured by the automatic rainfall and meteorological telemetry system in Taiwan: 
Diurnal and seasonal variations. Bull. Amer. Meteor. Soc., 80, 2299-2312, doi:10.1175/1520-0477(1999)080<2299: DASVOT $>2.0 . \mathrm{CO} ; 2$.

-_, S.-Y. Wang, W.-R. Huang, and M.-C. Yen, 2004: Variation of the East Asian summer monsoon rainfall. J. Climate, 17, 744-762, doi:10.1175/1520-0442(2004)017<0744: VOTEAS $>2.0 . \mathrm{CO} ; 2$.

,-- , and M.-C. Yen, 2007: Enhancement of afternoon thunderstorm activity by urbanization in a valley: Taipei. J. Appl. Meteor. Climatol., 46, 1324-1340, doi:10.1175/JAM2526.1.

Clappier, A., and Coauthors, 2000: Effect of sea breeze on air pollution in the greater Athens area. Part I: Numerical simulations and field observations. J. Appl. Meteor., 39, 546-562, doi:10.1175/1520-0450(2000)039<0546: EOSBOA $>2.0 . \mathrm{CO} ; 2$.

Clark, J. D., 1983: The GOES user's guide. NOAA/NESDIS, $165 \mathrm{pp}$.

Djurić, D., 1994: Weather Analysis, Prentice-Hall, 304 pp.

Eager, R. E., S. Raman, A. Wootten, D. L. Westphal, J. S. Reid, and A. A. Mandoos, 2008: A climatological study of the sea and land breezes in the Arabian Gulf region. J. Geophys. Res., 113, D15106, doi:10.1029/2007JD009710.

Faller, K., 2005: MTSAT-1R: A multifunctional satellite for Japan and the Asia-Pacific region. Proc. 56th Int. Astronautical Congress, Fukuoda, Japan, Int. Astronautical Federation, IAC-05-B3.2.04.

Fisher, E. L., 1960: An observational study of the sea breeze. J. Meteor., 17, 645-660, doi:10.1175/1520-0469(1960)017<0645: AOSOTS $>2.0 . \mathrm{CO} ; 2$.

Furberg, M., D. G. Steyn, and M. Baldi, 2002: The climatology of sea breezes on Sardinia. Int. J. Climatol., 22, 917-932, doi:10.1002/joc.780.

Hawkins, J. D., 1977: A study of the mesoscale wind circulation in a land-sea breeze regime. Bull. Amer. Meteor. Soc., 58, 1289-1295, doi:10.1175/1520-0477(1977)058<1289: ASOTMW $>2.0 . \mathrm{CO} ; 2$.

Hess, S. L., 1979: Introduction to Theoretical Meteorology. Krieger Publishing, $362 \mathrm{pp}$.

Hill, C. M., P. J. Fitzpatrick, J. H. Corbin, Y. H. Lau, and S. K. Bhate, 2010: Summertime precipitation regimes associated with the sea breeze and land breeze in southern Mississippi and eastern Louisiana. Wea. Forecasting, 25, 1755-1779, doi:10.1175/2010WAF2222340.1.

Huffman, G. J., and D. T. Bolvin, 2012: TRMM and other data precipitation data set documentation. NASA Goddard Space Flight Center Tech. Doc., 37 pp. [Available online at ftp://precip.gsfc.nasa.gov/pub/trmmdocs/3B42_3B43_ doc.pdf.]

Janowiak, J. E., R. J. Joyce, and Y. Yarosh, 2001: A real-time global half-hourly pixel resolution infrared dataset and its applications. Bull. Amer. Meteor. Soc., 82, 205-217, doi:10.1175/ 1520-0477(2001)082<0205:ARTGHH > 2.3.CO;2.

Jury, M. R., and S. Chiao, 2013: Leeside boundary layer confluence and afternoon thunderstorms over Mayaguez, Puerto Rico. J. Appl. Meteor. Climatol., 52, 439-454, doi:10.1175/ JAMC-D-11-087.1.

Kanamitsu, M., and Coauthors, 1991: Recent changes implemented into the Global Forecast System at NMC. Wea. Forecasting, 6, 425-435, doi:10.1175/1520-0434(1991)006<0425: RCIITG $>2.0 . \mathrm{CO} ; 2$.

Krishnamurti, T. N., 1979: Tropical Meteorology. Vol. II, Compendium of Meteorology, WMO-No. 364, World Meteorological Organization, Geneva, Switzerland, 428 pp.
Lawrence, M. G., 2005: The relationship between relative humidity and the dewpoint temperature in moist air. Bull. Amer. Meteor. Soc., 86, 225-233, doi:10.1175/ BAMS-86-2-225.

Liou, K. N., 2002: An Introduction to Atmospheric Radiation. 2nd ed. Academic Press, 583 pp.

Mastrantonio, G., I. Petenko, A. Viola, S. Argentini, L. Coniglio, P. Monti, and G. Leuzzi, 2008: Influence of the synoptic circulation on the local wind field in a coastal area of the Tyrrhenian Sea. IOP Conf. Ser.: Earth Environ. Sci., 1, 012049, doi:10.1088/1755-1315/1/1/012049.

Meyer, J. H., 1971: Radar observations of land breeze fronts. J. Appl. Meteor., 10, 1224-1232, doi:10.1175/1520-0450(1971)010<1224: ROOLBF $>2.0 . \mathrm{CO} ; 2$.

Miao, J.-F., L. J. M. Kroon, J. V.-G. de Arellano, and A. A. M. Holtslag, 2003: Impacts of topography and land degradation on the sea breeze over eastern Spain. Meteor. Atmos. Phys., 84, 157-170, doi:10.1007/s00703-002-0579-1.

Miller, L. J., and W. Anderson, 1991: Multiple Doppler radar wind synthesis in CEDRIC. NCAR CEDRIC manual appendix F, $12 \mathrm{pp}$.

Mizuma, M., 1995: General aspects of land and sea breezes in Osaka Bay and surrounding area. J. Meteor. Soc. Japan, 73, 1029-1040.

Morales Rodriguez, C. A., R. P. da Rocha, and R. Bombardi, 2010: On the development of summer thunderstorms in the city of São Paulo: Mean meteorological characteristics and pollution effect. Atmos. Res., 96, 477-488, doi:10.1016/ j.atmosres.2010.02.007.

Oliphant, A. J., A. P. Sturman, and N. J. Tapper, 2001: The evolution and structure of a tropical island sea/land breeze system, northern Australia. Meteor. Atmos. Phys., 78, 45-59, doi:10.1007/s007030170005.

Panchal, N. S., 1993: Onset characteristics of land/sea breeze circulation and its effect on meteorological parameters at a coastal site. Atmósfera, 6, 155-162.

Park, Y.-S., G.-H. Kim, T. Kwon, and Y.-J. Choi, 2012: Sea-land breeze observation using wind lidars in Korea. Extended $A b$ stracts, 16th Int. Symp. for the Advancement of Boundary-Layer Remote Sensing, Boulder, CO, NOAA/Earth System Research Laboratory/Physical Sciences Division, 178. [Available online at http://www.esrl.noaa.gov/psd/events/2012/isars/pdf/isars2012abstractVolume.pdf.]

Prtenjak, M. T., and B. Grisogono, 2007: Sea/land breeze climatological characteristics along the northern Croatian Adriatic coast. Theor. Appl. Climatol., 90, 201-215, doi:10.1007/ s00704-006-0286-9.

Sakurai, N., and Coauthors, 2011: Migration process and 3D wind field of precipitation systems associated with a diurnal cycle in west Sumatera: Dual Doppler radar analysis during the HARIMAU2006 campaign. J. Meteor. Soc. Japan, 89, 341361, doi:10.2151/jmsj.2011-404.

Sano, T., and K. Tsuboki, 2006: Structure and evolution of a cumulonimbus cloud developed over a mountain slope with the arrival of sea breeze in summer. J. Meteor. Soc. Japan, 84, 613640, doi: $10.2151 / \mathrm{jmsj} .84 .613$.

Shepherd, J. M., 2005: A review of current investigations of urbaninduced rainfall and recommendations for the future. Earth Interact., 9, doi:10.1175/EI156.1.

Simpson, J. E., 1994: Sea Breeze and Local Wind. Cambridge University Press, $234 \mathrm{pp}$

Wilson, J. W., E. E. Ebert, T. R. Saxen, R. D. Roberts, C. K. Mueller, M. Sleigh, C. E. Pierce, and A. Seed, 
2004: Sydney 2000 Forecast Demonstration Project: Convective storm nowcasting. Wea. Forecasting, 19, 131-150, doi:10.1175/1520-0434(2004)019<0131: SFDPCS $>2.0 . \mathrm{CO} ; 2$.

Yang, F., H. L. Pan, S. K. Krueger, S. Moorthi, and S. J. Lord, 2006: Evaluation of the NCEP Global Forecast System at the ARM SGP site. Mon. Wea. Rev., 134, 3668-3690, doi:10.1175/MWR3264.1.
Zhong, S., and E. S. Takle, 1992: An observational study of seaand land-breeze circulation in an area of complex coastal heating. J. Appl. Meteor., 31, 1426-1438, doi:10.1175/ 1520-0450(1992)031<1426:AOSOSA>2.0.CO;2.

- J. M. Leone Jr., and E. S. Takle, 1991: Interaction of the sea breeze with a river breeze in an area of complex coastal heating. Bound.-Layer Meteor., 56, 101-139, doi:10.1007/ BF00119964. 